\title{
Responses of Coastal Marine Microbiomes Exposed to Anthropogenic Dissolved Organic Carbon
}

\author{
Elena Cerro-Gálvez, Jordi Dachs, Daniel Lundin, María-Carmen Fernández-Pinos, Marta Sebastián, \\ and Maria Vila-Costa*
}

Cite This: Environ. Sci. Technol. 2021, 55, 9609-9621

Read Online

ABSTRACT: Coastal seawaters receive thousands of organic pollutants. However, we have little understanding of the response of microbiomes to this pool of anthropogenic dissolved organic carbon (ADOC). In this study, coastal microbial communities were challenged with $\mathrm{ADOC}$ at environmentally relevant concentrations. Experiments were performed at two Mediterranean sites with different impact by pollutants and nutrients: off the Barcelona harbor ("BCN"), and at the Blanes Bay ("BL"). ADOC additions stimulated prokaryotic leucine incorporation rates at both sites, indicating the use of $\mathrm{ADOC}$ as growth substrate. The percentage of "membranecompromised" cells increased with increasing ADOC, indicating concurrent toxic effects of ADOC. Metagenomic analysis of the BCN

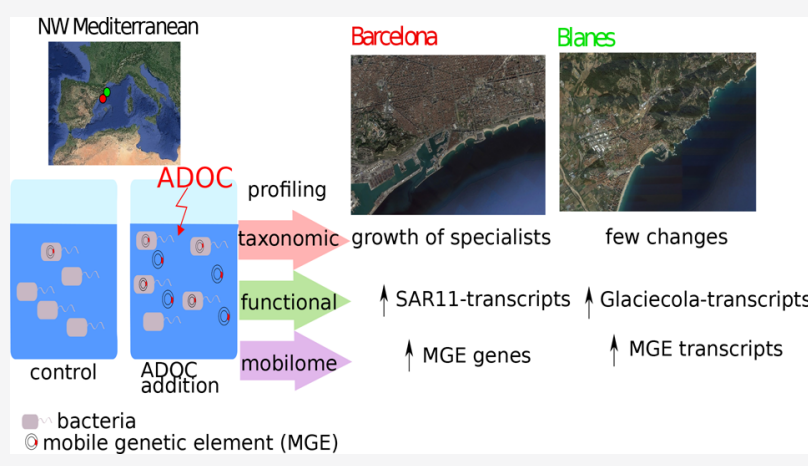
community challenged with ADOC showed a significant growth of Methylophaga and other gammaproteobacterial taxa belonging to the rare biosphere. Gene expression profiles showed a taxondependent response, with significantly enrichments of transcripts from SAR11 and Glaciecola spp. in BCN and BL, respectively. Further, the relative abundance of transposon-related genes (in $\mathrm{BCN}$ ) and transcripts (in $\mathrm{BL}$ ) correlated with the number of differentially abundant genes (in BCN) and transcripts (in BLA), suggesting that microbial responses to pollution may be related to pre-exposure to pollutants, with transposons playing a role in adaptation to ADOC. Our results point to a taxon-specific response to low concentrations of $\mathrm{ADOC}$ that impact the functionality, structure and plasticity of the communities in coastal seawaters. This work contributes to address the influence of pollutants on microbiomes and their perturbation to ecosystem services and ocean health.

KEYWORDS: organic pollutants, seawater, metatranscriptomics, metagenomics, plasticity, PAH, OPE, alkanes, marine microbial communities

\section{INTRODUCTION}

Chemical pollution is a poorly characterized vector of global change, ${ }^{1}$ especially under scenarios of chronic pollution such as the myriad of organic pollutants found at trace levels in the marine environment. ${ }^{2-4}$ Constraining this vector of global change is especially troublesome as most anthropogenic organic pollutants are unknown because of a lack of appropriate analytical procedures for their quantification. ${ }^{5}$ Anthropogenic dissolved organic carbon (ADOC) in coastal seawater originates from direct and indirect inputs of organic contaminants from rivers, effluents from wastewater treatment plants, continental runoff, groundwater, atmospheric deposition, and marine currents. ${ }^{3,6}$ The nonpolar (or hydrophobic) fraction of ADOC contains a large number of persistent chemicals that reach coastal waters, whereas many polar contaminants are at least partially biodegraded by microbiomes in wastewater treatment plants (WWTP) and during riverine transport. ${ }^{7}$ Hydrophobic ADOC derives from fossil fuels (mostly aliphatic and aromatic hydrocarbons), legacy persistent organic pollutants (POPs), organic pollutants of emerging concern (OPEC) $)^{8}$ and other anthropogenic chemicals. However, the myriad co-occurrences of hundreds of thousands of these anthropogenic chemicals at pico- and nanomolar concentrations can reach micromolar concentrations with still unquantified effects on ecosystems. ${ }^{3,6}$ Microbiome responses to ADOC include microbial degradation of some ADOC constituents under favorable conditions, but also a suite of antitoxic responses and adaptation strategies to ADOC. $^{9-12}$ The use of some POPs is restricted by

Special Issue: POPs on the Global Scale: Sources,

Distribution, Processes, and Lessons Learned for

Chemicals Management

Received: October 27, 2020

Revised: February 4, 2021

Accepted: February 4, 2021

Published: February 19, 2021 
international legislation such as the Stockholm Convention due to their toxicity, persistence, potential for long-range transport, and bioaccumulation potential. Nevertheless, chronic pollution by $\mathrm{ADOC}$ remains uncharacterized in terms of Earth System functioning. ${ }^{1}$ The characterization of the effects of this pollution on marine microbial communities at environmentally relevant $\mathrm{ADOC}$ concentrations has received limited attention, ${ }^{13,14}$ even though microbial communities play a pivotal role driving the planetary biogeochemical cycles.

A deeper understanding of the pertinent traits of marine microbiomes facing realistic ADOC concentrations is hence long overdue and would provide invaluable information to assess ecosystem health in the form of insight into the extraordinary ability of microorganisms to adapt to small environmental changes thanks to the vast genetic pool they harbor. ${ }^{15}$ The challenge is discriminating which traits-among those related to taxonomy, functionality and physiology-can serve as biomarkers under realistic environmental settings. First, changes in the composition of marine microbiomes in response to specific ADOC compounds have been thoroughly analyzed under exposure to high concentrations, as these studies are usually performed under scenarios of oil spills and other accidental events needing bioremediation approaches. For instance, oil spill accidents promoted the growth of hydrocarbonoclastic bacteria, including members of the rare biosphere, pointing to the presence of a seed bank of bacteria that can bloom under hydrocarbon-rich conditions. ${ }^{15}$ However, the ecotoxicological assessment for acute events has limited applicability on the influence of $\mathrm{ADOC}$ on microbial communities under low levels of chronic marine pollution. ${ }^{15,17-20}$ Whether or not environmentally relevant concentrations of $\mathrm{ADOC}$ are selecting for populations in marine communities, and how the response is modulated by community fitness or other microbiome traits is still unclear for remote environments, ${ }^{14}$ and it has never been assessed in coastal waters from populated regions. Second, at the functional level, only a few genes involved in degradation of ADOC compounds have been identified, mainly those coding for hydrocarbon-degradation enzymes, ${ }^{21}$ limiting the use of genes as functional biomarkers for the overall ADOC pool. ${ }^{22}$ Previous exploratory work showed wide genomic responses to ADOC,${ }^{14}$ but individual genes, as potential biomarkers, remain to be identified. Finally, at the physiological level, the impact of hydrophobic ADOC is generally focused on a few families of pollutants or oil extracts, representing only a partial view of ADOC effects. In terms of mass, the chromatographically unresolved complex mixture (UCM) is an important pool of the ADOC found in seawater, ${ }^{4,23}$ but it has received little attention in terms of effects to microbiomes. ${ }^{14,24}$ The handful of previous experiments that have challenged marine microbial communities with background concentrations of realistic ADOC mixtures, including the UCM, observed both biodegradation and a suite of physiological strategies against toxicity in heterotrophs and toxicological and inhibitory effects in phototrophs. ${ }^{14,25}$ These responses include those related to antioxidative stress and mechanisms to quench cell envelope stress, since hydrophobic ADOC strongly sorbs into membranes promoting harmful effects by narcosis, ${ }^{24-26}$ and other pollutant specific responses. ${ }^{12,14}$

Microbial responses to ADOC can be modulated by the history and environmental setting of the community. For example, pre-exposure of populations to low and high levels of contaminants modify the lag phase, rates, and extent of degradation. ${ }^{10,27,28}$ On the other hand, it has been shown that the adaptation of phytoplankton to organic pollutants can be modulated by dissolved organic carbon. ${ }^{29}$ Mobile genetic elements (MGE) promote genomic rearrangements and can take part in transfer of functional genes. ${ }^{30}$ In an environment exposed to pollutants, this can help spread genes involved in tolerance to pollutants, but also create genetic variation in the form of, for example, regulatory modifications, that, when modifying expression of genes involved in ADOC-response, can be picked up by selection. ${ }^{27,28,31-35}$ As high nutrient concentrations accelerate succession rates, ${ }^{36}$ these favor the proliferation of MGE within the communities ${ }^{36-38}$ potentially leading to an increase in evolvability through genomic rearrangements and gene transfer. The versatility of highly plastic marine microbiomes (with high abundances of MGEs) might result in higher potential for ADOC consumption and increased tolerance to $\mathrm{ADOC}$ compounds, since $\mathrm{MGE}$ represent a potent means of adaptation. ${ }^{33,39-42}$ However, few studies have addressed the synergistic effect of preadaptation and spread of MGEs for organic chemicals other than those dealing with antibiotics and their antibiotic resistance genes. ${ }^{4-45}$ Nevertheless, there is often the occurrence of multiple environmental stresses, for example, ADOC pollution at coastal sites is commonly linked to eutrophication, ${ }^{46}$ all of them driving microbial communities to higher plasticity potential.

The Mediterranean Sea is exposed to high anthropogenic pressures, ${ }^{47}$ but with considerable heterogeneity in their spatial distribution. The northwestern Mediterranean coast (Catalan coast, NE Iberian Peninsula) encompasses significant biological and physicochemical gradients including high variability in concentrations of micropollutants with higher levels closer to urban areas, ${ }^{48-51}$ and seasonal and spatial variations in nutrient limitation. ${ }^{52,53}$

In order to address the strategies to cope with hydrophobic ADOC within microbial communities in coastal systems, we performed experiments at two coastal sites from the NW Mediterranean with contrasting anthropogenic pressures in terms of pollutants and nutrients. The tested hypothesis was if microbial communities previously exposed to higher concentrations and more frequent pulses of organic contaminants and higher nutrient concentrations, show a higher plasticity that allow them to devote a higher percentage of their activity to consume these compounds than a less polluted and oligotrophic community. This was addressed by working at environmental relevant concentrations, analyzing the changes in microbial structure by metagenomics and changes in gene expression profiles by metatranscriptomic response (not only individual genes), and assessing the microbial response to the complex mixture of pollutants accounting for ADOC (not only individual pollutants).

\section{METHODS}

Sampling Site Description. Experiments were performed with seawater collected off the Barcelona harbor (BCN) and at the Blanes Bay Microbial Observatory (BL) (Supporting Information (SI) Figure S1). BCN is representative of a polluted eutrophic coastal site (yearly average Chla $>1.65 \mu \mathrm{g}$ / $\left.\mathrm{L}^{54}\right)$. BCN receives freshwater inputs from the highly polluted Besòs and Llobregat rivers, runoff from the city of Barcelona, and there are tons of accumulated legacy organic pollutants in the sediment from past uncontrolled release of sewage sludge 
that can be resuspended during storm events. Approximately $60 \mathrm{~km}$ north from Barcelona, Blanes Bay (BL, NW Mediterranean) is representative of a rather oligotrophic coastal site moderately affected by human influences with low terrestrial inputs of nutrients (yearly average Chla $<0.8$ $\left.\mu \mathrm{g} / \mathrm{L}^{55}\right)$.

Concentration of ADOC and Preparation of ADOC Spike Solutions. With the objective to prepare the ADOC spike solutions to be used in the experiments, As much as 200 $\mathrm{L}$ of surface seawater was collected from BCN (26th May $\left.2015 ; 41^{\circ} 22^{\prime} 16.4^{\prime \prime} \mathrm{N} 2^{\circ} 11^{\prime} 23.3^{\prime \prime} \mathrm{E}\right)$ and from a site located 50 $\mathrm{km}$ south of BCN (Vilanova i la Geltrú) with similar pollution levels than $\mathrm{BL}^{50}$ (6th June 2015; $41^{\circ} 06^{\prime} 48.0^{\prime \prime} \mathrm{N} 1^{\circ} 47^{\prime} 38.4^{\prime \prime} \mathrm{E}$ ) using several $20 \mathrm{~L}$ metal carboys. Briefly, seawater was concentrated on a XAD-2 adsorbent and eluted with dichloromethane and methanol. After concentration, extracts were fractionated on an aluminum oxide (alumina) column using solvents of different polarity. Concentration of three characteristic and ubiquitous families of hydrophobic organic compounds belonging to ADOC (organophosphate esters (OPEs) flame retardants and plasticizers, polycyclic aromatic hydrocarbons (PAHs), and $n$-alkanes) were analyzed using the methods previously described. ${ }^{4,12,56}$ The $24 n$-alkanes identified and quantified were a series from $\mathrm{nC}_{12}$ to $\mathrm{nC}_{35}$. The 64 target PAHs were naphthalene, methylnaphthalenes (sum of two isomers), dimethylnaphthalenes (sum of six isomers), trimethylnaphthalenes (sum of seven isomers), acenaphthylene, acenaphthene, fluorene, dibenzothiophene, methyldibenzothiophenes (sum of three isomers), dimethyldibenzothiopenes (sum of five isomers), phenanthrene, methylphenanthrenes (sum of four isomers), dimethylphenanthrenes (sum of seven isomers), fluoranthene, pyrene, methylpyrenes (sum of five isomers), dimethylpyrenes (sum of eight isomers), benzo $[g, h, i]$ fluoranthene, benzo $[a]$ anthracene, chrysene, methylchrysenes (sum of three isomers), benzo[a]pyrene, perylene, and dibenzo $[a, h]$ anthracene. The 10 OPEs were triisobutyl phosphate (TiBP), tri- $n$-butyl phosphate $(\mathrm{TnBP})$, tris $(2$ chloroethyl) phosphate (TCEP), tris(1-chloro-2-propyl) phosphate (TCPPs, 3 isomers), tris[2- chloro-1-(chloromethyl)ethyl] phosphate (TDCP), triphenyl phosphate (TPhP), 2ethylhexyl diphenyl phosphate (EHDPP), and tris(2-ethylhexyl) phosphate (TEHP).The most apolar fractions, fraction 1 and 2 (F1 and F2), contain hydrophobic hydrocarbons and synthetic organic compounds with a large contribution of an anthropogenic UCM. ${ }^{4,14,23}$ Both fractions were merged as representative of $\mathrm{ADOC}$, and used as spike solution in the experiments. This mixture of nonpolar ADOC is similar to that used in previous works. ${ }^{14,24,57,58}$

Experiments with Natural Communities. Coastal seawater was collected from the surface $(0.5 \mathrm{~m}$ depth) at a site close to Barcelona harbor mouth (16th June 2015, $41^{\circ} 22^{\prime} 16.4^{\prime \prime} \mathrm{N} 2^{\circ} 11^{\prime} 23.3^{\prime \prime} \mathrm{E}$, “BCN”), as representative of a polluted eutrophic coastal site, and Blanes Bay (22nd June $2015, \mathrm{BL}, 41^{\circ} 40^{\prime} 13.5^{\prime \prime} \mathrm{N} 2^{\circ} 48^{\prime} 00.6^{\prime \prime} \mathrm{E}$, "BL"), as representative of a rather oligotrophic site with moderate pollution (SI Figure $\mathrm{S} 1$ ). Responses to ADOC additions were analyzed in two experiment types: dose-response and bacterial response. (1) Dose-response experiment: marine microbiomes were challenged with four different exposure concentrations of ADOC $(1 \times, 7.5 \times, 40 \times$, and $240 \times$ in situ concentrations). ADOC spike solution in acetone was added to $40 \mathrm{~mL}$ glass tubes (previously baked, $450{ }^{\circ} \mathrm{C}, 4 \mathrm{~h}$ ) in the different treatments. The same volume of acetone with no ADOC was added to the controls. The acetone was let to evaporate under the hood for $2 \mathrm{~h}$ before seawater addition. To assess the importance of nutrient availability, we tested two different trophic conditions: an enrichment with $\mathrm{P}, \mathrm{N}$, and $\mathrm{C}\left(0.6 \mu \mathrm{M} \mathrm{NaH} \mathrm{PO}_{4} \cdot \mathrm{H}_{2} \mathrm{O}, 2\right.$ $\mu \mathrm{M}\left(\mathrm{NH}_{4}\right)_{2} \mathrm{SO}_{4}$ and $24 \mu \mathrm{M}$ glucose final concentration; "with nutrients"), to stimulate bacterial growth and prevent any potential nutrient limitation, and a control ("without nutrients"). Samples were incubated in duplicate in the dark at in situ temperature for $48 \mathrm{~h}$. Treatments of the experiments were run in duplicates. Monitoring of the abundance of prokaryotic cells, leucine incorporation rates (as a proxy of bacterial production), the percentage of damaged or dead cells (NADS-), and the abundance of actively respiring bacteria (CTC+) were performed after $0,4,24$, and $48 \mathrm{~h}$ of incubation (see below). (2) Bacterial responses to ADOC: A second set of experiments using the same seawater consisted on adding $7.5 \times$ ADOC concentrations dissolved in acetone to $2 \mathrm{~L}$ glass bottles (treatments), and only the solvent (acetone) to control bottles. The solvent was let to evaporate for $2 \mathrm{~h}$ before adding the seawater. The collected water was added to the glass bottles and incubated at in situ temperature and dark conditions for $24 \mathrm{~h}$. The experiment was run in duplicate. We collected and preserved samples for molecular analyses as described below at 0.5 and $24 \mathrm{~h}$. Additional samples were taken at the same time points to analyze prokaryotic abundance and production, and nutrient concentrations. The ADOC spike solution was generated from water of $\mathrm{BCN}$ and a location south of the $\mathrm{BCN}$ site, with similar pollution levels than $\mathrm{BL}^{50}$

Biological Parameters and Their Significance. Bacterial community structure was characterized by bacterial abundance determined by flow cytometry (SI Text S1) and by sequencing community DNA by metagenomics. Bacterial community activities were determined by $[3 \mathrm{H}]$ leucine incorporation rates (SI Text S1) as a proxy of bacterial production and by describing gene expression profiles by metatranscriptomics. General physiological characteristics of the microbial communities were characterized by nucleic-aciddouble-staining (NADS) viability protocol that enumerate the cells with intact versus damaged membranes and by the 5cyano-2,3-ditolyl tetrazolium chloride (CTC) protocol to quantify the abundance of highly respiring bacteria. Both NADS and CTC positive cells were quantified by flow cytometry. See details in the SI. ${ }^{59-, 62}$

Inorganic Nutrients Concentrations. Samples $(10 \mathrm{~mL})$ were kept frozen at $-20{ }^{\circ} \mathrm{C}$ until analysis of dissolved inorganic nutrient concentration (nitrite $\left(\mathrm{NO}_{2}^{-}\right)$, nitrate $\left(\mathrm{NO}_{3}{ }^{-}\right)$, ammonium $\left(\mathrm{NH}_{4}{ }^{+}\right)$, and phosphate $\left(\mathrm{PO}_{4}{ }^{3-}\right)$ ) were done. Measurements were performed by continuous flow analysis (CFA) on a Bran+Luebbe following Hansen and Koroleff. $^{63}$

Nucleic Acids Extraction and Sequencing. After 0.5 and $24 \mathrm{~h}$ incubations of the second experiment, each bottle was filtered through a $3 \mu \mathrm{m}$ pore-size $47 \mathrm{~mm}$ diameter polytetrafluoroethylene filter and bacterial cells were collected onto a $0.2 \mu \mathrm{m}$ pore-size $47 \mathrm{~mm}$ polytetrafluoroethylene filter under low vacuum pressure. The duration of the filtration step was no longer than $15 \mathrm{~min}$ to minimize RNA degradation. Each filter was cut in two halves, one was placed in $1 \mathrm{~mL}$ RNAlater (Sigma-Aldrich, Saint Louis, MO) and the other one into $1 \mathrm{~mL}$ lysis buffer $(50 \mathrm{mM}$ Tris $\mathrm{HCl}, 40 \mathrm{mM}$ EDTA, 0.75 $\mathrm{M}$ Sucrose) and stored at $-80{ }^{\circ} \mathrm{C}$ to preserve RNA and DNA, respectively. DNA extraction for metagenomic analyses was performed following the protocol described elsewhere. ${ }^{14}$ To 
estimate absolute gene counts, we added a DNA standard (Thermus thermophilus DSM7039 [HB27] genomic DNA) that functioned as internal control at $0.5 \%$ of the total mass of extracted DNA. mRNA for metatranscriptomic analyses was extracted and amplified as described somewhere else ${ }^{64}$ with the modification of the use of mirVana isolation kit (Ambion) to extract the total RNA. Artificial mRNA was synthesized by in vitro transcription from a pGEM-3Z plasmid and used as internal standard at $0.5 \%$ final concentration in order to calculate absolute transcript abundances. ${ }^{65,66}$ Resulting DNA and amplified RNA were sequenced at the National Center for Genomic Analysis (CNAG, Barcelona, Spain) using Illumina high output mode HS200 $2 \times 100 b p$ v4.

Bioinformatics. DNA (metagenomics) and cDNA (metatranscriptomics) sequences were quality trimmed and internal standards and any remaining stable RNA was quantified and removed using the ERNE mapping program ${ }^{67}$ against the internal standard sequences and an in-house database of marine bacterial stable RNA sequences, respectively. Archaeaharbored reads were eliminated of the analyses because of very low abundance. Subsequently, read pairs were joined using the PEAR program (https://www.h-its.org/en/research/sco/ software $\left.{ }^{68}\right)$. Joined pairs, as well as separate reads not corresponding to joined pairs were aligned to the NCBI RefSeq database (downloaded October 2016) using the Diamond aligner v0.8.25 $5^{69}$ in blastx mode with default parameters. The resulting alignments were taxonomically and functionally classified with MEGAN $6.5 .10^{70}$ and exported for further analysis in $\mathrm{R} /$ tidyverse. $^{71}$ Search for specific transposases was performed with Pfam profiles, using HMMER. ${ }^{72}$ The list of the specific Pfam profiles used is listed in Brazelton and Baross. ${ }^{73}$ Metagenomic analyses resulted in a total of 341 million paired-end reads and an average of 28.4 million reads per sample in a typical length of $101 \mathrm{bp}$. After quality-trimming and filtering of added internal standards, between 12.8 and $17.6 \%$ of the potential protein-coding reads were taxonomically annotated and between 32.5 and $47.9 \%$ were functionally annotated in SEED (SI Table S1). The sequencing of the metatranscriptomes resulted in a total of 949 million pairedend reads, 59.3 million raw reads per sample. After removal of rRNA, tRNA and internal standard reads, 369 million possible protein-encoding sequences remained, 23 million per sample. Among these, between 16.5 and 30.3 were taxonomically annotated and between 35.5 and 47.9 were successfully annotated to a SEED functional protein and category.

Statistical Analyses. Data treatment and statistical analyses were performed with the $\mathrm{R}$ Statistical Software. Significant differences between treatments were tested with $\mathrm{t}$ Student tests performed using the 't.test' function and Tukey's HSD posthoc test using the "TukeyHSD" with a threshold for the significance set at $p<0.05$. ANOVA were carried out using the "aov" function. Principal component analysis (PCA) and Permutational multivariate analysis of variance (PERMANOVA) were carried out using the Vegan package with standardized data. ${ }^{74}$ Analysis of differential gene abundances and differentially expressed genes was performed with the "EdgeR" package. ${ }^{75}$ Counts were normalized by internal standard recoveries to get absolute counts as described elsewhere. $^{67}$

\section{RESULTS AND DISCUSSION}

Initial Characterization of Sampling Sites. Level of Pollution. Three model families of ubiquitous organic pollutants (64 PAHs, $24 n$-alkanes and 10 OPEs) are surrogates of hydrophobic ADOC and were used to characterize the level of pollution at both sampling sites. On average, concentrations of dissolved PAHs, OPEs, and $n$-alkanes in BCN waters were 15-, 5- and 2-fold higher than those in "Vilanova i la Geltrú", respectively, which water was used in BL experiments (SI Figure S1, Table S2). The higher level of pollution in BCN than in "Vilanova i la Geltrú" or BL is consistent with previous work in this region that identified the Barcelona's metropolitan region as a source of organic pollutants to seawater sediments and waters. ${ }^{48,56,76,77}$ Indeed, the $\mathrm{BCN}$ site has been receiving large anthropogenic inputs of pollutants and nutrients from the impacted Besos and Llobregat rivers, atmospheric inputs from adjacent urban and industrial regions, WWTP effluents, runoff from the city of Barcelona, high shipping traffic, and tons of accumulated legacy organic pollutants in the sediment from past uncontrolled release of sewage sludge that can be resuspended during storm events. ${ }^{48,56,76,77}$ Measured concentrations at both sites were within the order of magnitude of concentrations previously measured in the same region. Specifically, the apparently dissolved concentrations of $n$-alkanes in our study $\left(\mathrm{n}-\mathrm{C}_{12}-\mathrm{n}-\mathrm{C}_{35}: 240 \mathrm{ng} / \mathrm{L}\right.$ in $\mathrm{BCN}$ and $110 \mathrm{ng} / \mathrm{L}$ in "Vilanova $\mathrm{i}$ la Geltrú", see SI Table S2 for details) were within the range of those reported in the NW Mediterranean Sea $\left(n-C_{15}-n-C_{40}\right.$ : $40-4600 \mathrm{ng} / \mathrm{L},{ }^{12,78,79}$ ) and in the Gulf of Gabès (SW Mediterranean) ( $\left.\mathrm{n}-\mathrm{C}_{15}-\mathrm{n}-\mathrm{C}_{40}: 20-6300 \mathrm{ng} / \mathrm{L}^{79}\right)$. The sum of $\mathrm{PAH}$ concentrations in the dissolved phase $\left(\sum_{64} \mathrm{PAH}: 1.2\right.$ $\mathrm{ng} / \mathrm{L}$ in $\mathrm{BCN}$ and $0.078 \mathrm{ng} / \mathrm{L}$ in "Vilanova i la Geltrú") were lower than those reported in coastal seawaters from the NW Mediterranean $\left(\sum_{15} \mathrm{PAH}\right.$ : $\left.3.6-30.7 \mathrm{ng} / \mathrm{L},{ }^{79}\right)$, but within the same range as in the open NW Mediterranean $\left(\sum_{19} \mathrm{PAH}\right.$ : $\left.0.16-0.81 \mathrm{ng} / \mathrm{L}^{56}\right)$. Among individual PAHs, phenanthrene was the most abundant compound $(0.21 \mathrm{ng} / \mathrm{L}$ in $\mathrm{BCN}$ and $0.028 \mathrm{ng} / \mathrm{L}$ in "Vilanova i la Geltrú") and the general profile was dominated by low molecular weight PAHs (2-4 rings), in agreement with previous studies. ${ }^{12,56,81-83}$ Concentrations of $\sum_{10} \mathrm{OPE}$ (46 ng/L in BCN and $8.4 \mathrm{ng} / \mathrm{L}$ in "Vilanova I la Geltrú") were in the range of those previously measured in NW Mediterranean Sea. ${ }^{12,84}$ Therefore, in the experiments, microbiomes were challenged to concentrations tipical of a large urban region $(\mathrm{BCN})$ or coastal midsize cities representative of NW Mediterranean ("Vilanova i la Geltrú" and $\mathrm{BL})$.

Level of Nutrients. Concentrations of nutrients were 8-fold higher in BCN than in BL (SI Table S3). Average concentrations of $\mathrm{NO}_{2}{ }^{-}+\mathrm{NO}_{3}{ }^{-}$were $3.6 \pm 0.01 \mu \mathrm{M}$ in $\mathrm{BCN}$, and $0.6 \pm 0.4 \mu \mathrm{M}$ in $\mathrm{BL}$. $\mathrm{NH}_{4}$ concentrations were $8.2 \pm$ 1.4 and $1.3 \pm 0.5 \mu \mathrm{mol} / \mathrm{L}$ in $\mathrm{BCN}$ and $\mathrm{BL}$, respectively, whereas $\mathrm{PO}_{4}{ }^{3-}$ concentrations were $0.5 \pm 0.05$ and $0.04 \pm$ $0.00 \mu \mathrm{M}$. These nutrient concentrations indicate a higher degree of eutrophication in $\mathrm{BCN}$ than in $\mathrm{BL}$ waters as previously described. ${ }^{54,55}$

Characterization of the Microbiomes. Abundances of heterotrophic cells quantified by flow cytometry were 0.9 - to 3.5-fold higher in BCN than in BL for both HNA and LNA cells (SI Table S4). At both sites, the heterotrophic bacterial community was dominated by HNA cells $(77.7 \pm 3.2 \%$ in $\mathrm{BCN}, 65.5 \pm 5.9 \%$ in $\mathrm{BL})$. Physiological traits of the communities indicated a higher proportion of active cells in $\mathrm{BCN}$ than in BL. Significantly higher leucine incorporation rates were observed in $\mathrm{BCN}$ than in $\mathrm{BL}(442.6 \pm 27.1 \mathrm{pmol}$ $\mathrm{Leu} / \mathrm{Lh}$ and $36.28 \pm 3.6 \mathrm{pmol} \mathrm{Leu} / \mathrm{L} \cdot \mathrm{h}$, respectively), as well 


\begin{tabular}{|c|c|c|c|c|c|c|c|c|c|c|c|c|c|}
\hline & & \multicolumn{5}{|c|}{$\mathrm{BCN}$} & \multicolumn{6}{|c|}{ BL } & \\
\hline & & \multicolumn{2}{|c|}{ Nutrients + } & \multicolumn{3}{|c|}{ Nutrients - } & \multicolumn{3}{|c|}{ Nutrients + } & \multicolumn{3}{|c|}{ Nutrients - } & \\
\hline & & $7.5 x$ & $40 x$ & $7.5 x$ & $40 x$ & $240 x$ & $7.5 x$ & $40 x$ & $240 x$ & $7.5 x$ & $40 x$ & $240 x$ & \\
\hline \multirow{3}{*}{$\begin{array}{l}\text { GR } \\
\text { cells } \mathrm{ml}^{-1} h^{-1}\end{array}$} & $4 \mathrm{~h}$ & $-0.12^{*}$ & 0.01 & -0.01 & -0.16 & -0.17 & 0.10 & 0.02 & 0.01 & -0.06 & 0.10 & -0.01 & \\
\hline & $24 \mathrm{~h}$ & 0.00 & 0.01 & -0.01 & 0.07 & -0.08 & 0.00 & 0.00 & 0.01 & 0.18 & -0.05 & 0.01 & 0 \\
\hline & $48 \mathrm{~h}-$ & -0.02 & -0.01 & -0.15 & -0.04 & 0.08 & -0.01 & 0.01 & -0.03 & 0.14 & 0.10 & 0.14 & \\
\hline \multirow{3}{*}{$\underset{\% \text { CTC+ }}{\text { CTC }}$} & $4 \mathrm{~h}$. & 0.01 & -0.01 & 0.01 & 0.04 & -0.04 & 0.02 & 0.05 & 0.02 & $0.09^{*}$ & 0.03 & 0.10 * & \\
\hline & $24 \mathrm{~h}-$ & 0.11 & 0.09 & 0.03 & 0.00 & -0.05 & $-0.05^{\star}$ & -0.02 & -0.00 & -0.03 & 0.10 & $0.17^{*}$ & \\
\hline & $48 \mathrm{~h}-$ & 0.02 & 0.02 & 0.03 & 0.00 & -0.18 & -0.02 & -0.06 & 0.06 & 0.02 & 0.08 & 0.13 & \\
\hline \multirow{3}{*}{$\begin{array}{l}\text { NADS } \\
\% \text { NADS dead }\end{array}$} & $4 \mathrm{~h}$. & 0.05 & $0.12^{*}$ & 0.06 & 0.18 * & 0.30 & -0.01 & 0.08 & $0.22^{*}$ & -0.68 & -0.33 & 0.02 & \\
\hline & $24 \mathrm{~h}-$ & -0.01 & 0.09 & -0.12 & -0.17 & 0.44 & 0.02 & 0.09 & 0.17 & -0.16 & 0.03 & $0.28^{*}$ & 0 \\
\hline & $48 \mathrm{~h}-$ & 0.03 & 0.37 & 0.32 & 0.22 & 0.85 & 0.11 & 0.18 & 0.28 & -0.16 & 0.01 & $0.19^{*}$ & -0. \\
\hline \multirow{3}{*}{$\begin{array}{l}\text { LIR } \\
\text { pmol Leu } L^{-1} h^{-1}\end{array}$} & $4 \mathrm{~h}-$ & -0.07 & $0.03^{*}$ & -0.06 & 0.02 * & -0.08 & 0.06 & -0.16 & $-0.07^{*}$ & -0.03 & -0.07 & 0.07 * & \\
\hline & $24 h^{-}$ & 0.01 & 0.03 & 0.00 & 0.08 & 0.10 & -0.05 & -0.02 & $-0.05^{*}$ & 0.04 & -0.00 & 0.12 * & 0 \\
\hline & $48 \mathrm{~h}^{-}$ & -0.03 & -0.01 & -0.05 & $0.03^{*}$ & $0.05^{*}$ & -0.11 & 0.01 & 0.03 & 0.03 & -0.01 & $0.10^{*}$ & -0 \\
\hline
\end{tabular}

Figure 1. Heatmap of changes in biological measurements between controls and ADOC amendments (calculated as logarithm of change) in the dose-response experiments. Significant differences $(t$ test; $P<0.05)$ between each treatment and control are marked with asterisks. GR: growth rates, LIR: leucine incorporation rates (bacterial production).

as a larger percentage of highly respiring cells (CTC+) $(6.5 \pm$ $0.2 \%$ and $2.7 \pm 0.2 \%$ in $\mathrm{BCN}$ and $\mathrm{BL}$, respectively). On the other hand, the proportion of dead cells (as determined by the NADS protocol) was 1.2-fold greater in $\mathrm{BCN}$ than in $\mathrm{BL}$. Significantly different composition was observed in both initial microbial communities according to metagenomic reads (PERMANOVA analyses, $R^{2}=0.82, P=0.002$ ). Proteobacteria was the dominant bacterial phylum in $\mathrm{BCN}$ and $\mathrm{BL}$ microbial communities, representing $68 \%$ and $76 \%$, respectively. Bacteroidetes was the next most abundant group (22\% in $\mathrm{BCN}$ and $11 \%$ in $\mathrm{BL}$ ) at both sites. At the class level, Alphaproteobacteria was the most abundant (31\% in BCN and $53 \%$ in $\mathrm{BL}$ ), but the most abundant groups differed between locations at the order level. Rhodobacterales order was the most dominant Alphaproteobacteria (up to $12 \%$ ) at $\mathrm{BCN}$, whereas SAR11 accounted for a higher percentage (up to 31\%) at $\mathrm{BL}$. The contrasting relative abundance of the copiotrophs Rhodobacterales at BCN and the oligotrophs SAR11 at BL also reflects the different trophic status of the waters. ${ }^{85}$

Transposases were significantly more abundant in BCN than in $\mathrm{BL}$ metagenomes $(0.05 \pm 0.006 \%$ of total metagenomic reads in $\mathrm{BCN}$ and $0.03 \pm 0.0005 \%$ in $\mathrm{BL}, t$ test, $P<0.05$ ) (SI Figure S2). The higher abundances of MGEs are consistent with the $\mathrm{BCN}$ microbial community being exposed to anthropogenic stresses such as higher pollution and variable nutrient pulses. ${ }^{30,40,41}$ Similarly, highly impacted regions of the inner Baltic Sea have been shown to have higher abundances of transposases than in the adjacent marine waters. ${ }^{42}$

Thus, the concurrent high concentrations of pollutants, nutrients and MGEs agrees with a community in BCN adapted to episodes of high ADOC concentrations and nutrients variability, whereas in $\mathrm{BL}$, waters were more oligotrophic and bacteria had a lower abundance of MGEs, consistent with a lower pre-exposure to anthropogenic stressors which presumably yielded a less resilient community.

Effect of Nutrient Addition Without ADOC Additions. Nutrient addition (ammonium, dihydrogen phosphate and glucose) in the controls increased bacterial production 4.2-fold at BCN and 1.2-fold at BL after $48 \mathrm{~h}$ of incubation (SI Table S4). Significantly higher percentages of CTC-respiring cells were observed in nutrient amended controls at both sites after $48 \mathrm{~h}$. Cell numbers of heterotrophic cells (LNA as well as HNA) doubled in the nutrient amended controls at both sites, and were especially high for LNA cells after $48 \mathrm{~h}$ (SI Table S4). The percentage of dead cells (NADS-) decreased during the incubation, showing a lower decrease in nutrient amendments at BCN (from 10.8 to $5.0 \%$ ) than at BL (from 34 to $9.6 \%$ ). These results show an overall stimulation of the community upon nutrient amendment at both sites in agreement with previous studies in NW Mediterranean coastal waters. ${ }^{52,53}$ Nutrient addition included addition of inorganic $\mathrm{N}$ and $\mathrm{P}$ forms plus labile organic $\mathrm{C}$. The higher in situ concentrations of inorganic nutrients in $\mathrm{BCN}$ seawater than in $\mathrm{BL}$ and the higher increase of bacterial production in $\mathrm{BCN}$ than in BL seawaters and the similar increases of CTCrespiring cells at both sites, suggest a stronger limitation of labile $\mathrm{C}$ to build biomass in BCN microbiomes than in BL.

Responses to ADOC with and without Nutrient Additions. The dose-response experiment of ADOC treatments, with and without nutrient amendments, originated changes in physiological traits of the microbiomes, with changes more notable in the absence of nutrient additions (Figure 1). At BL, the percentage of highly respiring cells (CTC+) followed a similar trend as bacterial production, increasing steadily from low values similar to controls at $7.5 \times$ $\mathrm{ADOC}$ addition (7.4\% of CTC+ cells), to higher numbers at $240 \times$ ADOC additions (12.7\% of CTC+ cells) under ambient 


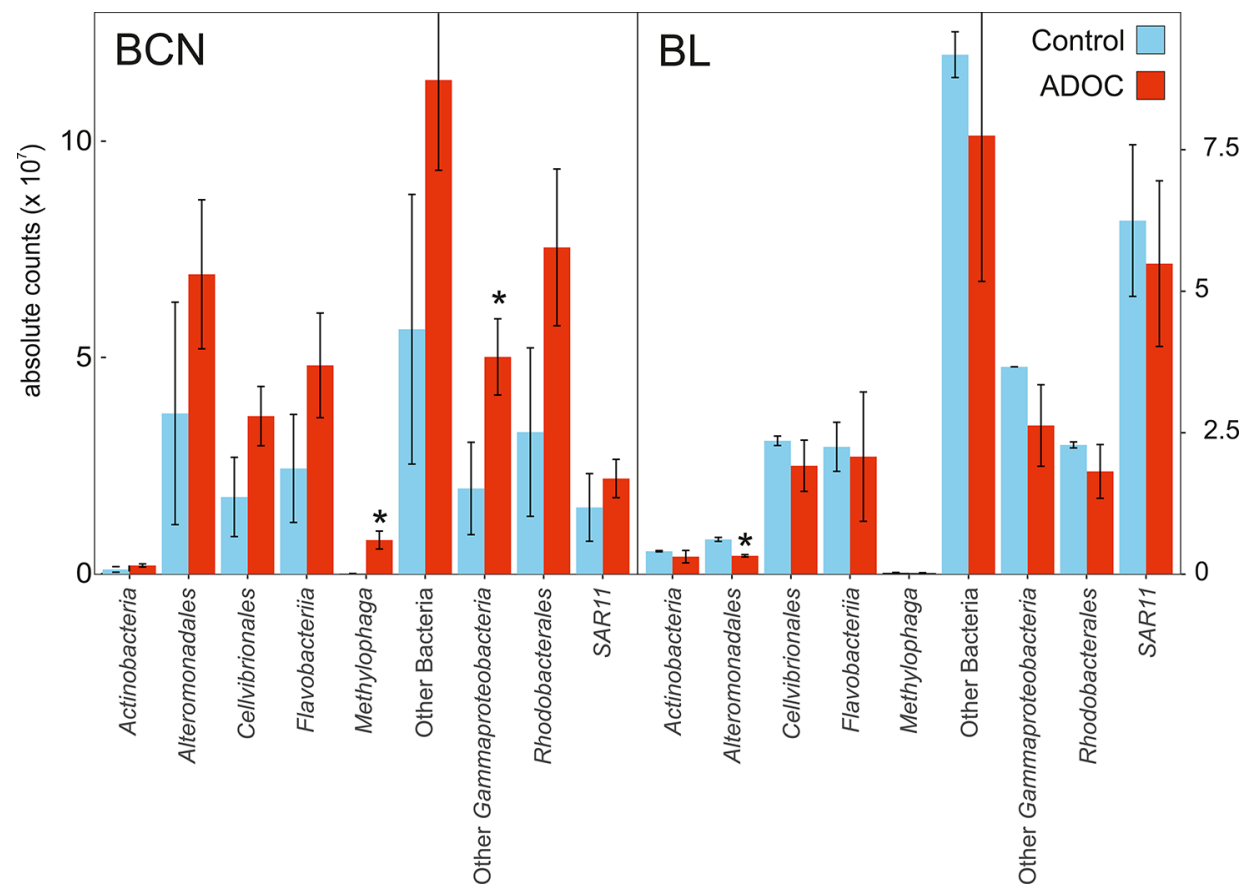

Figure 2. Taxonomical composition of Barcelona and Blanes metagenomes after $24 \mathrm{~h}$ of ADOC exposure. Asterisks indicate significant differences between $\mathrm{ADOC}$ amendments and controls $(t$ test; $p<0.05)$. Values are means of duplicates. Error bars show standard deviation. ADOC: ADOC amendment.

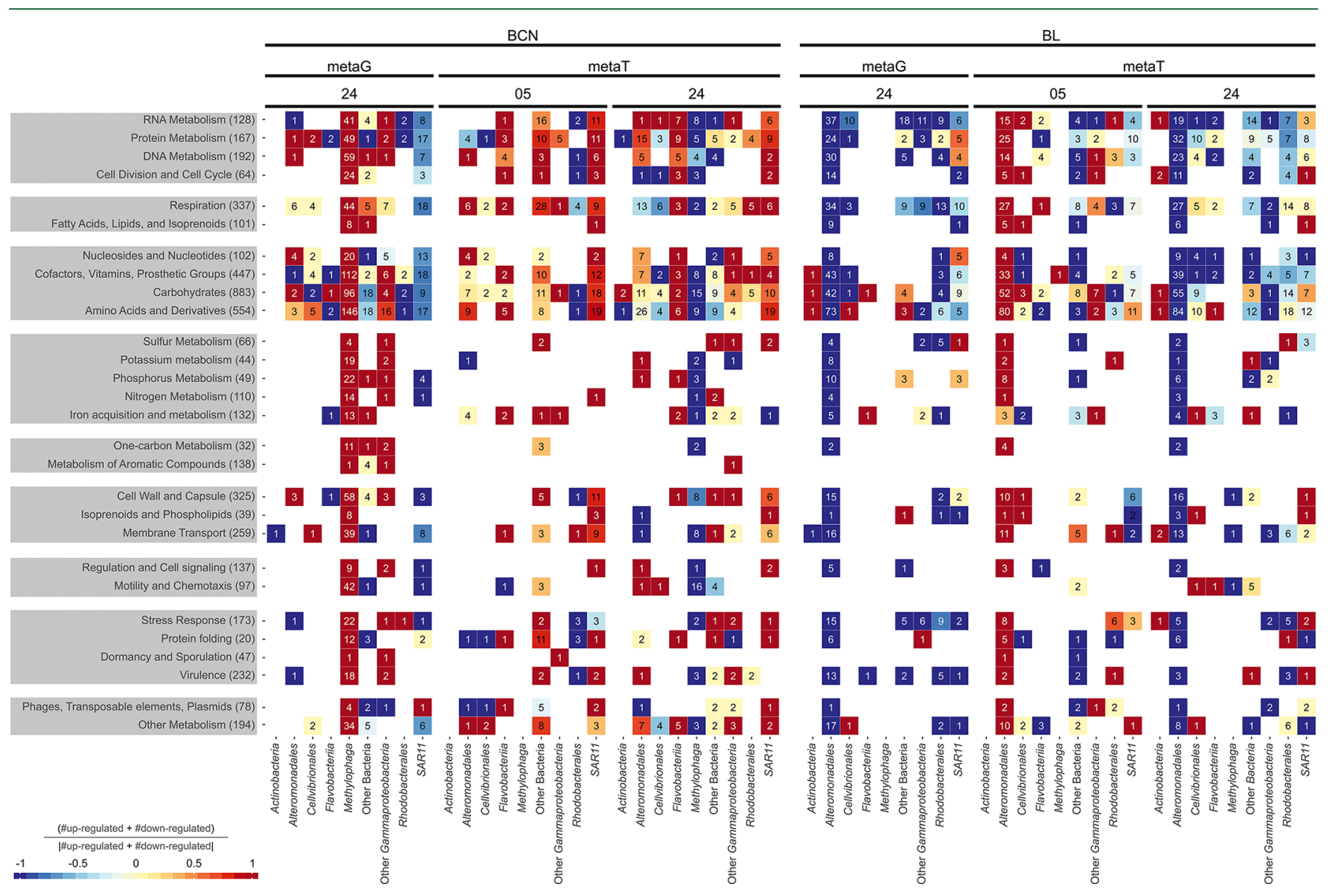

Figure 3. Total number of significantly enriched (in red) or depleted (in blue) genes and transcripts detected by edgeR (FDR $<0.05$ ) in the experiments when comparing ADOC treatments and controls. Counts indicated inside each tile mean the number of genes with significant differences in that SEED category. Rows correspond to SEED categories and the value in parentheses is the total number of genes or transcripts that belong to that category. 


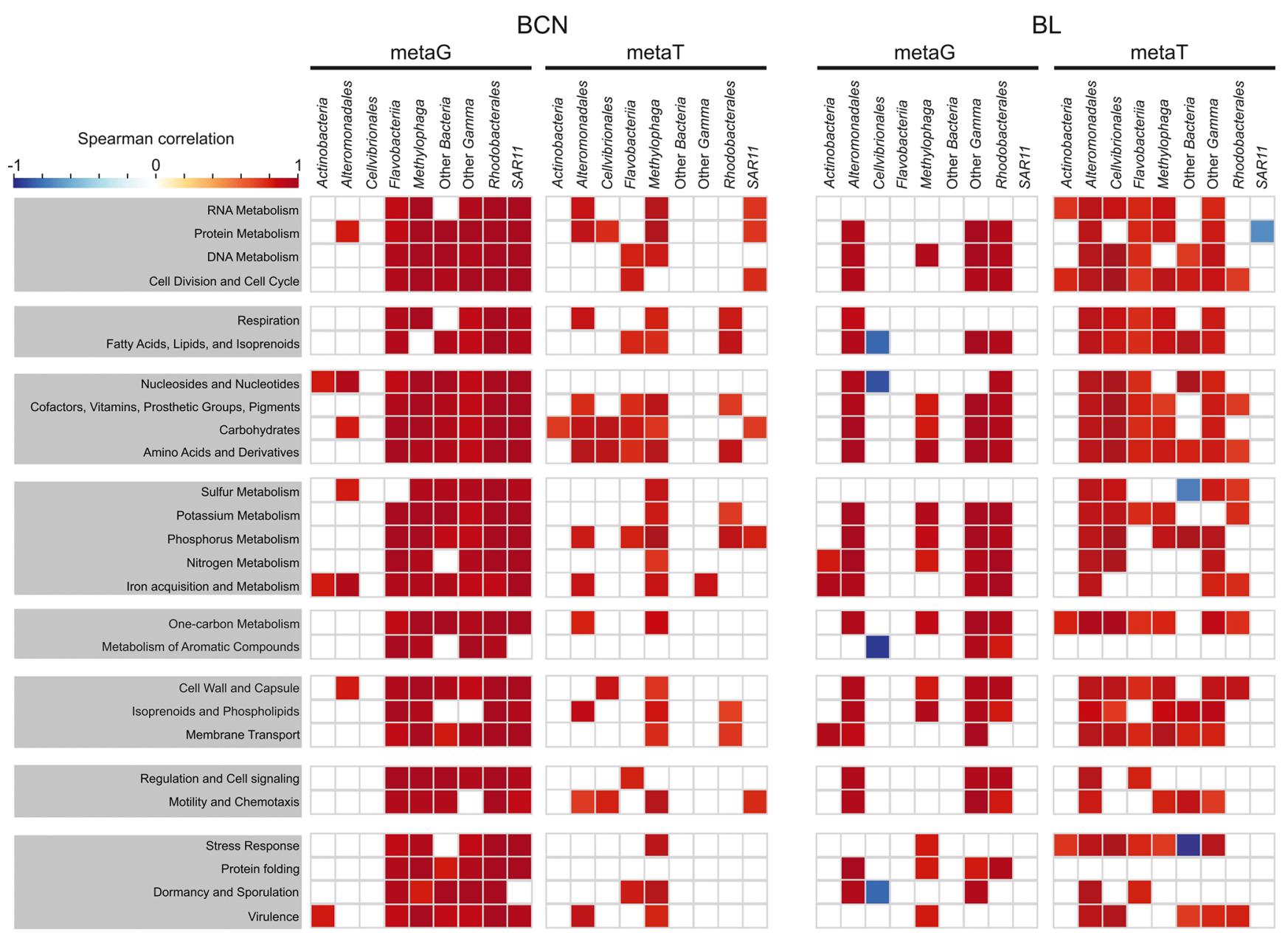

Figure 4. Spearman's correlations between the relative abundance of transposons and the genes/transcripts that were significantly different between treatments and controls. Rows correspond to SEED categories.

nutrient availability (Figure 1 and SI Figure S3). BCN communities did not show significant differences of CTC+ percentages between treatments and controls at any time or trophic condition. The percentage of CTC+ and LNA and HNA abundances, bacterial production and growth rates were positively correlated in the experiments (SI Figure S4). The percentage of dead cells (NADS-) relative to the total number of bacterial cells steadily increased with ADOC additions in BL, irrespective of nutrient availability (SI Figure S5). A similar pattern was observed in increases of NADS- along with ADOC amendments in $\mathrm{BCN}$ experiments, but with a lower magnitude. The percentage of dead cells increased, with a concurrent increase of biomass as shown by the positive correlation between dead cells and growth rates $(N=54$, Pearson's $r=$ $0.49, P<0.05$; SI Figure S4). These results suggest that ADOC compounds were used as a substrate for growth by at least part of the microorganisms. As ADOC additions also led to an increased number of dead cells, especially in BL, ADOC produced a toxic effect on prokaryotes in addition to being a source of carbon and nutrients as previously observed in polar microbiomes. ${ }^{14}$ Community responses to ADOC under nutrient limiting conditions were then studied at gene level by means of metagenomic and metatranscriptomic approaches.

Changes in Community Composition and Gene Content Due to Exposure to Background ADOC Concentrations. Metagenome responses to the effects of low concentrations of ADOC were studied after 0.5 and $24 \mathrm{~h}$ in incubations without nutrient additions. Treatments were done with a nominal increase of $7.5 \times$ ADOC compared to in situ concentrations. The nominal organic pollutant concentrations in the treatments fell in the range of $0.6-8.9 \mathrm{ng} / \mathrm{L}$ for $\sum_{32} \mathrm{PAH}, 63-343 \mathrm{ng} / \mathrm{L}$ for $\sum_{10} \mathrm{OPE}$ and $802-1767 \mathrm{ng} / \mathrm{L}$ for $\sum_{24}$ alkanes $\left(n-C_{12}-n-C_{35}\right)$. These concentrations are similar to those previously measured in the dissolved phase of the Mediterranean Sea. ${ }^{12,80,84,86}$ Furthermore, for hydrophobic and semivolatile ADOC chemicals, it is known that real exposure concentrations are lower than nominal (spiked) concentrations due to adsorption to bottle walls, partitioning to cells, losses by volatilization, etc. ${ }^{14,24}$ Thus, cells were exposed to low ADOC concentrations, within the range of environmental variability.

ADOC addition promoted a notable change of the community composition in the BCN microbiome (SI Figure S6). Principal component analyses (PCA) indicated that Rhodobacterales and Gammaproteobacteria, especially the Methylophaga genus, were the most responsive bacteria to ADOC at the expense of SAR11 and Flavobacteriia (SI Figure S6). Significant ( $p$-value $<0.05$ ) increases of Methylophaga and other Gammaproteobacteria populations were observed in $\mathrm{ADOC}$ treatments after $24 \mathrm{~h}$ (Figure 2). In BL, a significant decrease of Alteromonadales abundances was observed after 24 $\mathrm{h}$ between controls and ADOC treatments (Figure 2). At the functional level, after $24 \mathrm{~h}$ of incubation, different functional categories directly related to $\mathrm{ADOC}$ metabolism significantly increased in the $\mathrm{BCN}$ metagenomes, such as the metabolism of 


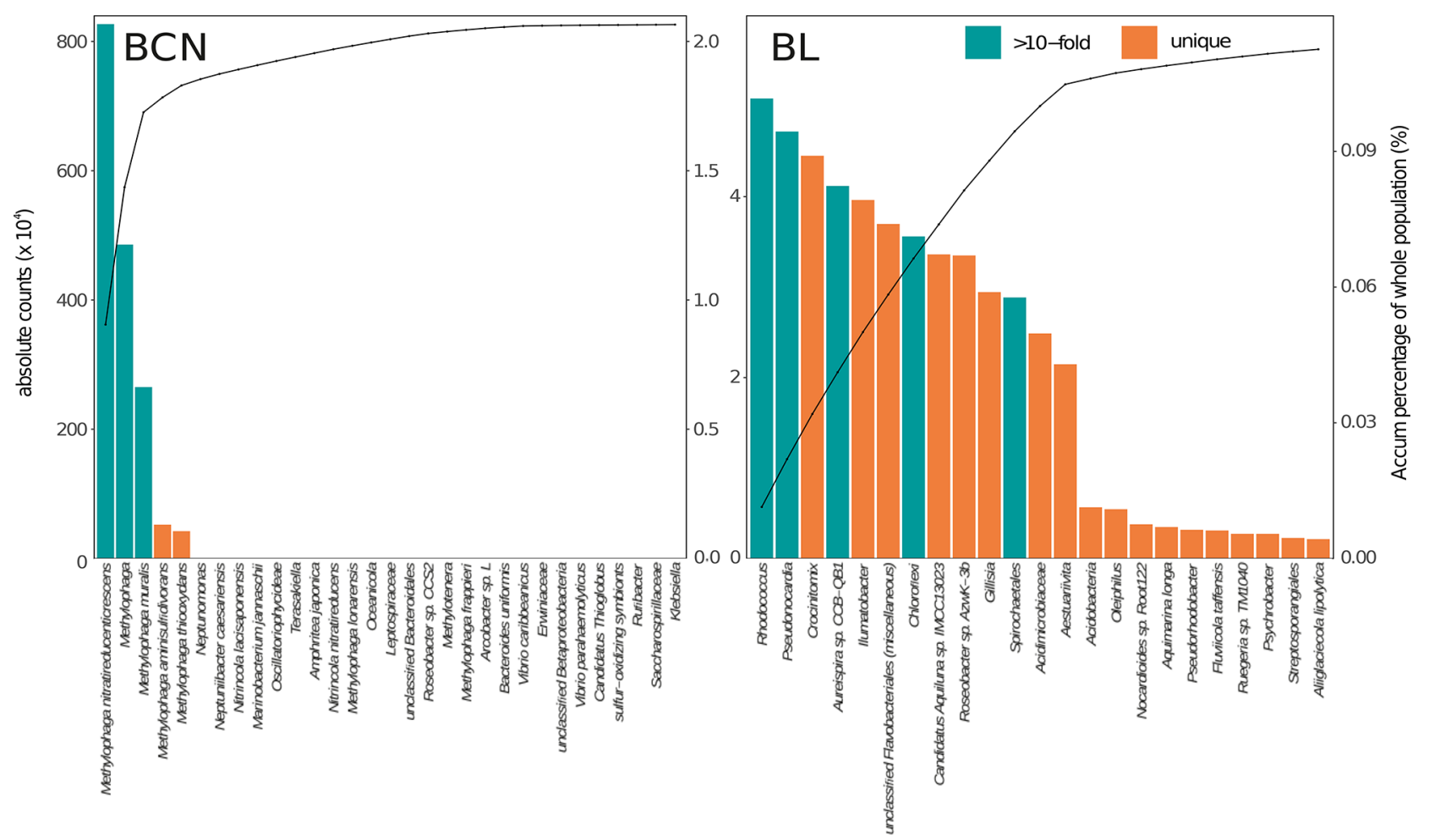

Figure 5. Growth of the rare biosphere. Abundances in the taxa that increased by 10 -fold (green) or were absent in controls (orange) after $24 \mathrm{~h}$ of incubation in the Barcelona (BCN) and Blanes (BL) ADOC amendment. Phylotypes were taxonomically classified at highest resolution. Counts were summarized at each taxonomical level.

aromatic compounds and oxidative stress, mostly harbored by Rhodobacterales and Gammaproteobacteria (SI Table S5; Figure S7; $t$ test, $p<0.05$ ). Most of the significantly differentially abundant genes following ADOC incubations in $\mathrm{BCN}$ were harbored by Methylophaga and other Gammaproteobacteria (Figure 3) and were positively correlated with the relative abundance of transposases in the metagenomes (Figure 4), a trend observed in BL only for Alteromonas, other Gammaproteobacteria, and Rhodobacterales. Similarly, exposure of river biofilm to wastewater treatment plants (WWTP) waters has been shown to induce a concurrent dissemination of antibiotic resistance genes (ARGs) and MGEs. ${ }^{45} \mathrm{BL}$ metagenomes showed a general decrease of significantly differentially abundant genes, especially those harbored by Alteromonadales (Figure 3).

Growth of Methylophaga in BCN was especially relevant since they were at very low abundances in the initial community, constituting less than $0.03 \%$, thus belonging to the rare biosphere. The taxa that increased in abundance more than 10-fold in ADOC treatments than in controls, or that were absent in controls but present in the treatments after 24 $\mathrm{h}$, increased from $0.12 \%$ of total community in initial waters to $2.06 \%$ in ADOC treatments after $24 \mathrm{~h}$ (Figure 5). The fast ADOC-growing rare biosphere was mostly composed of Methylophaga species and other Gammaproteobacteria taxa in BCN (Figure 5). Specifically, Methylophaga spp. in the treatments, were 70 -fold more abundant than in the controls. Similar increases were observed for other described ADOCdegrading genera such as Alcanivorax (2.1-fold increase), Nocardioides (2.1-fold increase), and Pseudomonas (2.3-fold increase) (SI Figure $S 8^{21}$ ). In BL, ADOC-stimulated taxa belonged to different groups, mostly Actinobacteria and Flavobacteriia, but their contribution to the total communities remained low (from $0.09 \%$ to $0.11 \%$ of total reads) after $24 \mathrm{~h}$ (Figure 5). Increases of specialized ADOC-consumers from the rare biosphere following ADOC pulses have been observed both at low concentrations in polar seawaters, ${ }^{14}$ and at high concentrations following oil spill accidents. ${ }^{16,17,87}$ Methylopha$g a$ has been identified as an efficient hydrocarbon degrader in seawater ${ }^{88}$ and it can become enriched following oil spills. ${ }^{16}$ In the plume originated by the Deepwater Horizon oil spill in the Gulf of Mexico, methylotrophs in general were enriched in the community following increases of ADOC-degrading specialists. ${ }^{89,90}$ This can be explained by Methylophaga spp. having the capacity to remove methyl-groups from alkylated hydrocarbons, for example methyl phenanthrenes, that are generally abundant in the ocean ${ }^{4}$ and were abundant in the original ADOC (SI Table S2). This demethylation could be fast, and could thus have the potential to trigger an increase of methylotrophic transcripts after $24 \mathrm{~h}$. Previous work has described methylotrophs after $24 \mathrm{~h}$ of exposure to ADOC in the $\operatorname{Arctic}^{14}$ and after several days when high MW DOC is degraded. $^{91}$

Gene Expression Profiles after ADOC Additions. Significantly enriched transcripts after $30 \mathrm{~min}$ and $24 \mathrm{~h}$ of ADOC addition were mostly related to heterotrophic activities of the cells, such as respiration, but also to effects on cells such as oxidative stress (Figure 3). Furthermore, an important number of transcripts related to cell wall and membrane transport and composition were enriched in the $\mathrm{ADOC}$ treatments, as previously observed in polar microbiomes. ${ }^{14}$ These transcriptomic responses are in agreement with the fact that hydrophobic ADOC accumulates in the membrane with concentrations many orders of magnitude higher than in seawater, inducing perturbation of cell membrane's permeability, rigidity, and efficiency by inducing narcosis. ${ }^{92,93}$ 
All these responses were taxon-specific (Figure 3). The significant enrichment of transcripts related to antitoxicity strategies for SAR11 and Flavobacteriia in BCN and Alteromonadales, mostly the genus Glaciecola, in BL contrasted with a decrease of their relative abundance in the metagenomes after $24 \mathrm{~h}$ of ADOC incubation. In contrast, transcripts of the growing Methylophaga group could not be captured after 30 min and they were significantly depleted after $24 \mathrm{~h}$. These trends can be explained by the coexistence in the communities of $\mathrm{ADOC}$ tolerant groups, $\mathrm{ADOC}$-degrading taxa, groups negatively affected by $\mathrm{ADOC}$, and by the different temporal responses to ADOC effects in the communities. ${ }^{35,94}$ The ADOC-degrading populations in a community can be tracked using genes and transcripts related to described degrading genes such as those included in the aromatic compounds SEED category. Although few of these transcripts were observed in the metatranscriptomes, significant enrichments of the aromatic compounds SEED category were observed in Rhodobacterales and some Gammaproteobacteria in ADOC challenged metagenomes (Figure 3 and SI Figure S7). In contrast, ADOC-tolerant communities may not grow on ADOC, but have a suite of antitoxicity strategies to cope with the pressure due to exposure to ADOC. These strategies, summarized for exposure to oil spills $^{95}$ and to low concentrations of ADOC, ${ }^{14}$ allow them to compete with ADOC-degraders for the available nutrients. For example, as consumers of $\mathrm{C} 1$ chemicals, Methylophaga may not have the capacity to degrade ADOC compounds, but only the $\mathrm{C} 1$ compounds released by other bacteria. There were significant correlations between Methylophaga-harbored transposases and many significantly differentially abundant genes and transcripts between ADOC enrichments and the control, including those related to stress response, membrane transport, isoprenoids and cell walls ${ }^{14}$ (Figure 4). This suggests that the adaptation process in Methylophaga is at least partially related to MGE and methylotrophy (Figures 3 and 4). Another potential ADOCtolerant community member was SAR11. SAR11 expressed most of the significantly differentially abundant transcripts in BCN microbiomes after 0.5 and $24 \mathrm{~h}$, although did not significantly grow in cell number during the $24 \mathrm{~h}$ (Figure 3 ). A similar pattern for this group was observed in polar waters ${ }^{14}$ and was attributed to a higher tolerance to hydrophobic chemicals. For instance, SAR11 has a less hydrophobic cell surface compared to other taxa, ${ }^{96}$ which lowers the extent of adsorption of $\mathrm{ADOC}$ compounds and in turn lowers the risk of narcosis.

Alteromonadales accounted for most of the enriched transcripts after $0.5 \mathrm{~h}$ and most of the depleted ones after 24 $\mathrm{h}$ in $\mathrm{BL}$ transcriptomes (Figure 3). Most of the active Alteromonadales in BL corresponded to Glaciecola spp., a group that dominated the phenanthrene-tolerant community in NW Mediterranean coast, but not the phenanthrenedegrading community. ${ }^{35}$ These authors observed that Glaciecola accounted for most of the ${ }^{12} \mathrm{C}$-fraction after stableisotope probing (SIP) incubations adding ${ }^{12} \mathrm{C}$ - and ${ }^{13} \mathrm{C}$ phenanthrene in the less polluted sites (Marseille and Banyuls), with similar levels than BL bay. Our work agrees with these previous results and shows that Glaciecola cell activation can be observed at much lower ADOC concentrations (from $\mathrm{mg} / \mathrm{L}$ in elsewhere ${ }^{35}$ to $\mathrm{ng} / \mathrm{L}$ in our study).

Do Pre-Exposed Microbiomes Show an Adaptation to Chronic ADOC Pollution? The results obtained at the $\mathrm{BCN}$ and $\mathrm{BL}$ contrasting sites show a complex response to
ADOC for two microbiomes with different previous exposure to $\mathrm{ADOC}$ and other environmental pressures. A surprising trend was the dissimilarity at both sites between metagenome and metatranscriptome responses to $\mathrm{ADOC}$ that could also be related to the different plasticity of $\mathrm{BCN}$ and $\mathrm{BL}$ microbiomes. Transposon genes were generally correlated with differentially abundant genes in $\mathrm{BCN}$, but to a lower degree in BL. Conversely, transcripts of transposons were generally correlated with differential abundant transcripts in $\mathrm{BL}$, but to a lower degree in BCN (Figure 4). As far as we know, this is the first time that transposons are measured using both metagenomes and metatranscriptomes under experimental conditions simulating an environmental stress (ADOC in this case). With the information available and current knowledge on the role of MGE it is not possible to provide a conclusive explanation to the patterns shown in Figure 4. We point here to a number of plausible explanations that will require further experimental validation such as (i) acquired plasticity versus developing plasticity, (ii) kinetic issues, (iii) trophic lifestyle of the community.

First, the results obtained suggest that potentially adapted communities, such as the ones from $\mathrm{BCN}$, show transposons correlated with the genes responding to the stress. Conversely, in less adapted communities, such as in $\mathrm{BL}$, the transcripts of transposons are generally correlated with the oxidative stressrelated transcripts (Figure 4). The lack of significant changes of the bacterial community in $\mathrm{BL}$, suggests that populations with the capacity to better withstand ADOC were lacking, or present at very low abundances, in the starting community, in contrast to the clearly more preadapted community in BCN that responded with differential growth of populations. During a longer time-span, ADOC-adapted populations may become detectable, and the increased expression of transposons that we observed in BL may have adaptive effects on the community. This may come in the form of horizontal transfer of ADOCrelated genes associated with transposons, but possibly also as structural effects on genomes, that alter expression patterns. In $\mathrm{BCN}$, pre-exposure to $\mathrm{ADOC}$ presumably originated a better adapted community to ADOC-induced stress. Transposons, like other MGEs, are often linked to fitness-related genes, in this case genes related to exposure to $\mathrm{ADOC}$-defense genes. The transmission of these genes to a new genome likely increases the likelihood that the transposon will remain in the community. ${ }^{97}$ Evidence of linkages between MGEs and adaptive genes to organic pollutants have been observed in several bacterial isolates. ${ }^{33}$ One would thus expect to find more transposons in a community exposed recently to environmental stresses like pollution or antibiotics such in BCN to a greater extend than in BL. Previous studies have shown the concurrent dissemination (and correlation) of MGEs and tolerance genes such as antibiotic resistance genes (ARG). ${ }^{98,99}$ As far as we know, this is the first study that shows multiple correlations between MGEs (transposases) and the functions known to respond to stress, in this case exposure to ADOC. This observation will need further experimental validation.

Second, issues related to the time needed to respond to ADOC could also be behind the trends shown in Figure 4, as at both sites the metagenome and metatranscriptome were sampled after $24 \mathrm{~h}$ which could represent different stages of the microbial response to ADOC. Thus, another hypothesis is that Figure 4 mirrors a faster response for the more preadapted $\mathrm{BCN}$ population, but reflects the early stages of adaptation for the BL population. The influence of adaptation has received 
some attention in the terms of degradation processes. Preexposure of the $\mathrm{BCN}$ bacterial communities to ADOC and other anthropogenic pressures probably conferred to them a greater capacity to degrade ADOC compounds, as well as a higher transposons density (Figure 4 and SI Figure S2).

Third, the higher degree of eutrophication in BCN waters favored a higher abundance of copiotrophic bacteria. Copiotrophic bacteria harbor larger genomes than oligotrophic bacteria, with potentially higher number of transposons genes. However, while copiotroph genomes can be $20 \%$ larger than oligotrophs, ${ }^{100}$ the occurrence of MGE in copiotrophs versus oligotrophs has not yet been studied in marine bacteria. On the contrary, a recent work on soil bacteria chronology during forest recovery showed higher numbers of transposon genes in oligotrophic than copiotrophic bacteria, ${ }^{101}$ indicating that the abundance of these MGE depends mainly on the history of environmental changes (transitions between different environmental pressures) rather than on the level of environmental pressure (high nutrients). This counter-example suggests that the higher abundance of copiotrophs in $\mathrm{BCN}$ waters cannot explain their higher number of transposon genes, which may be related to a history of changing environmental pressures in terms of pollutants and nutrients. Furthermore, the higher abundance of copiotrophs in BCN does not explain the differences in $\mathrm{ADOC}$ responses in the metaT and metaG profiles in BCN and BL. In a previous work, coastal microbial communities in a eutrophic bay in the East China Sea under long-term WWTP's effluent disturbances were less sensitive to inorganic nutrient input than a community free from direct anthropogenic disturbances. ${ }^{102}$

Future research will need to confirm the observations suggesting a potential relationship between MGE and responses to $\mathrm{ADOC}$. As $\mathrm{ADOC}$ concentrations are increasing during the Anthropocene, this is an issue that will require further experimentation and an ambitious research agenda.

Refs 59, 60, 61, 62, 99

\section{ASSOCIATED CONTENT}

\section{SI Supporting Information}

The Supporting Information is available free of charge at https://pubs.acs.org/doi/10.1021/acs.est.0c07262.

Text S1, Tables S1-S5, and Figures S1-S8 (PDF)

\section{AUTHOR INFORMATION}

\section{Corresponding Author}

Maria Vila-Costa - Department of Environmental Chemistry, IDAEA-CSIC, Barcelona, Catalunya 08034, Spain; ○ orcid.org/0000-0003-1730-8418; Email: maria.vila@ idaea.csic.es

\footnotetext{
Authors

Elena Cerro-Gálvez - Department of Environmental Chemistry, IDAEA-CSIC, Barcelona, Catalunya 08034, Spain

Jordi Dachs - Department of Environmental Chemistry, IDAEA-CSIC, Barcelona, Catalunya 08034, Spain; (1) orcid.org/0000-0002-4237-169X

Daniel Lundin - Centre for Ecology and Evolution in Microbial Model Systems, EEMiS, Linnaeus University, Kalmar 35195, Sweden
}

María-Carmen Fernández-Pinos - Department of Environmental Chemistry, IDAEA-CSIC, Barcelona, Catalunya 08034, Spain

Marta Sebastián - Department of Marine Biology and Oceanography, ICM-CSIC, Barcelona, Catalunya 08003, Spain

Complete contact information is available at: https://pubs.acs.org/10.1021/acs.est.0c07262

\section{Notes}

The authors declare no competing financial interest.

\section{ACKNOWLEDGMENTS}

This work was supported by the Spanish Ministry of Economy and Competitiveness (MEIC) through projects ISOMICS (CTM2015-65691-R) and REMARCA (CTM2012-34673). E.C.G. was supported by Agència de Gestió d'Ajuts Universtaris i Recerca, Generalitatde Catalunya (FI AGAUR) Scholarship, Generalitat de Catalunya Fellowship Program (Catalan Government, Generalitat de Catalunya) and by a "FORD ESPANNA-APADRINA LA CIENCIA" contract. The research group of Global Change and Genomic Biogeochemistry is supported by the Catalan Government (2017SGR800). We thank Dr. J. M. Gasol for support with flow cytometry counts. Inorganic nutrient analyses were performed by M. I. Abad in coordination with Dr. E. Berdalet (Head of the Service) at the "Nutrient Analysis Service of the ICM-CSIC. Dr Piña is acknowledged for fruitful discussions.

\section{REFERENCES}

(1) Rockström, J.; Steffen, W.; Noone, K.; Persson, Å.; Chapin, F. S.; Lambin, E. F.; Lenton, T. M.; Scheffer, M.; Folke, C.; Schellnhuber, H. J.; Nykvist, B.; de Wit, C. A.; Hughes, T.; van der Leeuw, S.; Rodhe, H.; Sörlin, S.; Snyder, P. K.; Costanza, R.; Svedin, U.; Falkenmark, M.; Karlberg, L.; Corell, R. W.; Fabry, V. J.; Hansen, J.; Walker, B.; Liverman, D.; Richardson, K.; Crutzen, P.; Foley, J. A. A safe operating space for humanity. Nature 2009, 461, 472-475.

(2) Jones, K. C.; De Voogt, P. Persistent organic pollutants: State of the Science. Environ. Pollut. 1999, 100, 209-221.

(3) Dachs, J.; Méjanelle, L. Organic pollutants in coastal waters, sediments, and biota: A relevant driver for ecosystems during the anthropocene? Estuaries Coasts 2010, 33, 1-14.

(4) González-Gaya, B.; Fernández-Pinos, M.-C.; Morales, L.; Méjanelle, L.; Abad, E.; Piña, B.; Duarte, C. M.; Jiménez, B.; Dachs, J. High atmosphere-ocean exchange of semivolatile aromatic hydrocarbons. Nat. Geosci. 2016, 9, 438-442.

(5) Muir, D. C. G.; Howard, P. H. Are there other persistent organic pollutants? A challenge for environmental chemists. Environ. Sci. Technol. 2006, 40, 7157-66.

(6) Vila-Costa, M.; Cerro-Gálvez, E.; Martínez-Varela, A.; Casas, G.; Dachs, J. Anthropogenic dissolved organic carbon and marine microbiomes. ISME J. 2020, 14, 2646-2648.

(7) Gioia, R.; Dachs, J. The riverine input-output paradox for organic pollutants. Front. Ecol. Environ. 2012, 10, 405-406.

(8) Sauvé, S.; Desrosiers, M. A review of what is an emerging contaminant. Chem. Cent. J. 2014, 8, 1-7.

(9) Head, I. M.; Jones, D. M.; Röling, W. F. M. Marine microorganisms make a meal of oil. Nat. Rev. Microbiol. 2006, 4, 173-182.

(10) Boyd, T. J.; Smith, D. C.; Apple, J. K.; Hamdan, L. J.; Osburn, C. L.; Montgomery, M. T. Evaluating PAH biodegradation relative to total bacterial carbon demand in coastal ecosystems: are PAHs truly recalcitrant? Microbial Ecol. Res. Trends 2008, 1-38.

(11) Cravo-Laureau, C., Lauga, B., Cagnon, C.; Duran, R. Microbial responses to pollution-ecotoxicology: Introducing the different 
biological levels. In Microbial Ecotoxicology; Springer: Cham, 2017, $45-62$.

(12) Cerro-Gálvez, E.; Sala, M. M.; Marrasé, C.; Gasol, J. M.; Dachs, J.; Vila-Costa, M. Modulation of microbial growth and enzymatic activities in the marine environment due to exposure to organic contaminants of emerging concern and hydrocarbons. Sci. Total Environ. 2019, 678, 486-498.

(13) Cavicchioli, R.; Ripple, W. J.; Timmis, K. N.; Azam, F.; Bakken, L. R.; Baylis, M.; Behrenfeld, M. J.; Boetius, A.; Boyd, P. W.; Classen, A. T.; Crowther, T. W.; Danovaro, R.; Foreman, C. M.; Huisman, J.; Hutchins, D. A.; Jansson, J. K.; Karl, D. M.; Koskella, B.; Mark Welch, D. B.; Martiny, J. B. H.; Moran, M. A.; Orphan, V. J.; Reay, D. S.; Remais, J. V.; Rich, V. I.; Singh, B. K.; Stein, L. Y.; Stewart, F. J.; Sullivan, M. B.; van Oppen, M. J. H.; Weaver, S. C.; Webb, E. A.; Webster, N. S. Scientists' warning to humanity: microorganisms and climate change. Nat. Rev. Microbiol. 2019, 17, 569-586.

(14) Cerro-Gálvez, E.; Casal, P.; Lundin, D.; Piña, B.; Pinhassi, J.; Dachs, J.; Vila-Costa, M. Microbial responses to anthropogenic dissolved organic carbon in Arctic and Antarctic coastal seawaters. Environ. Microbiol. 2019, 21, 1466-1481.

(15) Caruso, G.; La Ferla, R.; Azzaro, M.; Zoppini, A.; Marino, G.; Petochi, T.; Corinaldesi, C.; Leonardi, M.; Zaccone, R.; Umani, S. F.; Caroppo, C.; Monticelli, L.; Azzaro, F.; Decembrini, F.; Maimone, G.; Cavallo, R. A.; Stabili, L.; Todorova, N. H.; Karamfilov, V. K.; Rastelli, E.; Cappello, S.; Acquaviva, M. I.; Narracci, M.; De Angelis, R.; Del Negro, P.; Latini, M.; Danovaro, R. Microbial assemblages for environmental quality assessment: knowledge, gaps and usefulness in the European Marine Strategy Framework Directive. Crit. Rev. Microbiol. 2016, 42, 883-904.

(16) Kleindienst, S.; Grim, S.; Sogin, M.; Bracco, A.; CrespoMedina, M.; Joye, S. B. Diverse, rare microbial taxa responded to the Deepwater Horizon deep-sea hydrocarbon plume. ISME J. 2016, 10, 400-415.

(17) Hazen, T. C.; Dubinsky, E. A.; DeSantis, T. Z.; Andersen, G. L.; Piceno, Y. M.; Singh, N.; Jansson, J. K.; Probst, A.; Borglin, S. E.; Fortney, J. L.; Stringfellow, W. T.; Bill, M.; Conrad, M. E.; Tom, L. M.; Chavarria, K. L.; Alusi, T. R.; Lamendella, R.; Joyner, D. C.; Spier, C.; Baelum, J.; Auer, M.; Zemla, M. L.; Chakraborty, R.; Sonnenthal, E. L.; D'haeseleer, P.; Holman, H. Y.; Osman, S.; Lu, Z.; Van Nostrand, J. D.; Deng, Y.; Zhou, J.; Mason, O. U. Deep-sea oil plume enriches indigenous oil-degrading bacteria. Science 2010, 330, 204208.

(18) Kostka, J. E.; Prakash, O.; Overholt, W. A.; Green, S. J.; Freyer, G.; Canion, A.; Delgardio, J.; Norton, N.; Hazen, T. C. Hydrocarbondegrading bacteria and the bacterial community response in Gulf of Mexico beach sands impacted by the Deepwater Horizon oil spill. Appl. Environ. Microbiol. 2011, 77, 7962-7974.

(19) Megharaj, M.; Ramakrishnan, B.; Venkateswarlu, K.; Sethunathan, N.; Naidu, R. Bioremediation approaches for organic pollutants: A critical perspective. Environ. Int. 2011, 37, 1362-1375.

(20) Birrer, S. C.; Dafforn, K. A.; Johnston, E. L. Microbial community responses to contaminants and the use of molecular techniques. In Microbial Ecotoxicology; Springer International Publishing: Cham, 2017, 165-183.

(21) Ghosal, D.; Ghosh, S.; Dutta, T. K.; Ahn, Y. Current state of knowledge in microbial degradation of polycyclic aromatic hydrocarbons (PAHs): A review. Front. Microbiol. 2016, 7, 1369.

(22) Winderl, C.; Schaefer, S.; Lueders, T. Detection of anaerobic toluene and hydrocarbon degraders in contaminated aquifers using benzylsuccinate synthase ( $b s s A)$ genes as a functional marker. Environ. Microbiol. 2007, 9, 1035-1046.

(23) White, H. K.; Xu, L.; Hartmann, P.; Quinn, J. G.; Reddy, C. M. Unresolved Complex Mixture (UCM) in coastal environments is derived from fossil sources. Environ. Sci. Technol. 2013, 47, 726-731.

(24) Fernández-Pinos, M.-C.; Vila-Costa, M.; Arrieta, J. M.; Morales, L.; González-Gaya, B.; Piña, B.; Dachs, J. Dysregulation of photosynthetic genes in oceanic Prochlorococcus populations exposed to organic pollutants. Sci. Rep. 2017, 7, 8029.
(25) van Wezel, A. P.; Opperhuizen, A. Narcosis due to environmental pollutants in aquatic organisms: Residue-based toxicity, mechanisms, and membrane burdens. Crit. Rev. Toxicol. $1995,25,255-279$.

(26) Mitchell, A. M.; Silhavy, T. J. Envelope stress responses: balancing damage repair and toxicity. Nat. Rev. Microbiol. 2019, 17, 417-428.

(27) Aelion, C. M.; Dobbins, D. C.; Pfaender, F. K. Adaptation of aquifer microbial communities to the biodegradation of xenobiotic compounds: Influence of substrate concentration and preexposure. Environ. Toxicol. Chem. 1989, 8, 75-86.

(28) Okere, U. V.; Cabrerizo, A.; Dachs, J.; Ogbonnaya, O.; Jones, K. C.; Semple, K. T. Effects of pre-exposure on the indigenous biodegradation of $14 \mathrm{C}$ phenanthrene in Antarctic soils. Int. Biodeterior. Biodegrad. 2017, 125, 189-199.

(29) Rizzuto, S.; Thrane, J. E.; Baho, D. L.; Jones, K. C.; Zhang, H.; Hessen, D. O.; Nizzetto, L.; Leu, E. Water Browning Controls Adaptation and Associated Trade-Offs in Phytoplankton Stressed by Chemical Pollution. Environ. Sci. Technol. 2020, 54, 5569-5579.

(30) Ullastres, A.; Merenciano, M.; Guio, L.; González, J. Transposable Elements: A Toolkit for Stress and Environmental Adaptation in Bacteria. Stress and Environmental Regulation of Gene Expression and Adaptation in Bacteria, I \& II: Wiley, 2016; pp 137145.

(31) Ojo, O. A. (2007) Molecular strategies of microbial adaptation to xenobiotics in natural environment. Biotechnol. Mol. Biol. Rev. 2007, No. 2, 1-13.

(32) Haritash, A. K.; Kaushik, C. P. Biodegradation aspects of polycyclic aromatic hydrocarbons (PAHs): A review. J. Hazard. Mater. 2009, 169, 1-15.

(33) Top, E. M.; Springael, D. The role of mobile genetic elements in bacterial adaptation to xenobiotic organic compounds. Curr. Opin. Biotechnol. 2003, 14, 262-269.

(34) Greenwood, P. F.; Wibrow, S.; George, S. J.; Tibbett, M. Hydrocarbon biodegradation and soil microbial community response to repeated oil exposure. Org. Geochem. 2009, 40, 293-300.

(35) Sauret, C.; Gilles, V.; Guigue, C.; Tatiana, S.; Goutx, M.; Pujopay, M.; Conan, P.; Fagervold, S. K. 'Rare biosphere' bacteria as key phenanthrene degraders in coastal seawaters. Environ. Pollut. 2014, 194, 246-253.

(36) Knelman, J. E.; Schmidt, S. K.; Lynch, R. C.; Darcy, J. L.; Castle, S. C.; Cleveland, C. C.; Nemergut, D. R. Nutrient addition dramatically accelerates microbial community succession. PLoS One 2014, 9, e102609.

(37) Schä, H.; Bernard, L.; Courties, C.; Lebaron, P.; Servais, P.; Pukall, R.; Stackebrandt, E.; Troussellier, M.; Guindulain, T.; VivesRego, J.; Muyzer, G. Microbial community dynamics in Mediterranean nutrient-enriched seawater mesocosms: changes in the genetic diversity of bacterial populations. FEMS Microbiol. Ecol. 2001, 34, 243-253.

(38) Amos, G. C.; Gozzard, E.; Carter, C. E.; Mead, A.; Bowes, M. J.; Hawkey, P. M.; Zhang, L.; Singer, A. C.; Gaze, W. H.; Wellington, E. M. (2015). Validated predictive modeling of the environmental resistome. ISME J. 2015, 9, 1467-1476.

(39) Müller, T. M.; Werlen, C.; Spain, J.; van der Meer, J. R. Evolution of a chlorobenzene degradative pathway among bacteria in a contaminated groundwater mediated by a genomic island in Ralstonia. Environ. Microbiol. 2003, 5, 163-173.

(40) Frost, L. S.; Leplae, R.; Summers, A. O.; Toussaint, A. Mobile genetic elements: the agents of open source evolution. Nat. Rev. Microbiol. 2005, 3, 722-732.

(41) Casacuberta, E.; González, J. The impact of transposable elements in environmental adaptation. Mol. Ecol. 2013, 22, 15031517.

(42) Vigil-Stenman, T.; Ininbergs, K.; Bergman, B.; Ekman, M. High abundance and expression of transposases in bacteria from the Baltic Sea. ISME J. 2017, 11, 2611-2623. 
(43) Gillings, M. R. Evolutionary consequences of antibiotic use for the resistome, mobilome and microbial pangenome. Front. Microbial. 2013, 4, 4.

(44) Lekunberri, I.; Balcázar, J. L.; Borrego, C. M. Metagenomic exploration reveals a marked change in the river resistome and mobilome after treated wastewater discharges. Environ. Pollut. 2018, $234,538-542$.

(45) Subirats, J.; Timoner, X.; Sànchez-Melsió, A.; Balcázar, J. L.; Acuña, V.; Sabater, S.; Borrego, C. M. Emerging contaminants and nutrients synergistically affect the spread of class 1 integron-integrase (intI1) and sul1 genes within stable streambed bacterial communities. Water Res. 2018, 138, 77-85.

(46) Dachs, J.; Eisenreich, S. J.; Hoff, R. M. Influence of eutrophication on air- water exchange, vertical fluxes, and phytoplankton concentrations of persistent organic pollutants. Environ. Sci. Technol. 2000, 34, 1095-1102.

(47) Durrieu de Madron, X.; Guieu, C.; Sempéré, R.; Conan, P.; Cossa, D.; D’Ortenzio, F.; Estourneli, C.; Gazeau, F.; Rabouille, C.; Stemmann, L.; Bonnet, S.; Diaz, F.; Koubbi, P.; Radakovitch, O.; Babin, M.; Baklouti, M.; Bancon-Montigny, C.; Belviso, S.; Bensoussan, N.; Bonsang, B.; Bouloubassi, I.; Brunet, C.; Cadiou, J.-F.; Carlotti, F.; Chami, M.; Charmasson, S.; Charrière, B.; Dachs, J.; Doxaran, D.; Dutay, J.-C.; Elbaz-Poulichet, F.; Eléaume, M.; Eyrolles, F.; Fernandez, C.; Fowler, S.; Francour, P.; Gaertner, J. C.; Galzin, R.; Gasparini, S.; Ghiglione, J.-F.; Gonzalez, J.-L.; Goyet, C.; Guidi, L.; Guizien, K.; Heimbürger, L.-E.; Jacquet, S. H. M.; Jeffrey, W. H.; Joux, F.; Le Hir, P.; Leblanc, K.; Lefêvre, D.; Lejeusne, C.; Lemé, R.; LoÿePilot, M.-D.; Mallet, M.; Méjanelle, L.; Mélin, F.; Mellon, C.; Mérigot, B.; Merle, P.-L.; Migon, C.; Miller, W. L.; Mortier, L.; Mostajir, B.; Mousseau, L.; Moutin, T.; Para, J.; Pérez, T.; Petrenko, A.; Poggiale, J.-C.; Prieur, L.; Pujo-Pay, M.; Pulido-Villenab; Raimbault, P.; Rees, A. P.; Ridame, C.; Rontani, J.-F.; Ruiz Pino, D.; Sicre, M. A.; Taillandier, V.; Tamburini, C.; Tanaka, T.; Taupier-Letage, I.; Tedetti, M.; Testor, P.; Thébault, H.; Thouvenin, B.; Touratier, F.; Tronczynski, J.; Ulses, C.; Van Wambeke, F.; Vantrepotte, V.; Vaz, S.; Verney, R. Marine ecosystems' responses to climatic and anthropogenic forcings in the Mediterranean. Prog. Oceanogr. 2011, 91, 97166.

(48) García-Flor, N.; Guitart, C.; Ábalos, M.; Dachs, J.; Bayona, J. M.; Albaigés, J. Enrichment of organochlorine contaminants in the sea surface microlayer: An organic carbon-driven process. Mar. Chem. 2005, 96, 331-345.

(49) Berrojalbiz, N.; Dachs, J.; Del Vento, S.; Ojeda, M. J.; Valle, M. C.; Castro-Jiménez, J.; Mariani, J.; Wollgast, J.; Hanke, G. Persistent organic pollutants in Mediterranean seawater and processes affecting their accumulation in plankton. Environ. Sci. Technol. 2011, 45, 43154322.

(50) Sánchez-Ávila, J.; Tauler, R.; Lacorte, S. Organic micropollutants in coastal waters from NW Mediterranean Sea: Sources distribution and potential risk. Environ. Int. 2012, 46, 50-62.

(51) Castro-Jiménez, J.; Berrojalbiz, N.; Méjanelle, L.; Dachs, J. Sources, transport and deposition of atmospheric organic pollutants in the Mediterranean Sea. ACS Symp. Ser. 2013, 1149, 231-260.

(52) Sala, M. M.; Peters, F.; Gasol, J.; Pedrós-Alió, C.; Marrasé, C.; Vaqué, $\mathrm{D}$. Seasonal and spatial variations in the nutrient limitation of bacterioplankton growth in the northwestern Mediterranean. Aquat. Microb. Ecol. 2002, 27, 47-56.

(53) Pinhassi, J.; Gómez-Consarnau, L.; Alonso-Sáez, L.; Sala, M. M.; Vidal, M.; Pedrós-Alió, C.; Gasol, J. Seasonal changes in bacterioplankton nutrient limitation and their effects on bacterial community composition in the NW Mediterranean Sea. Aquat. Microb. Ecol. 2006, 44, 241-252.

(54) Arin, L.; Guillén, J.; Segura-Noguera, M.; Estrada, M. Open sea hydrographic forcing of nutrient and phytoplankton dynamics in a Mediterranean coastal ecosystem. Estuarine, Coastal Shelf Sci. 2013, 133, 116-128.

(55) Gasol, J. M.; Massana, R.; Simó, R.; Marrasé, C.; Acinas, S. G.; Pedrós-Alió, C.; Pelejero, C.; Sala, M. M.; Calvo, E.; Vaqué, D.; Peters, F. Blanes Bay (Site 55). In ICES Phytoplankton and Microbial
Ecology Status Report 2010/2012; O’Brien, T. D., Li, W. K. W., Morán, X. A. G., Eds.; 2012, 138-141.

(56) Berrojalbiz, N.; Dachs, J.; Ojeda, M. J.; Valle, M. C.; CastroJiménez, J.; Wollgast, J.; Ghiani, M.; Hanke, G.; Zaldivar, J. M. Biogeochemical and physical controls on concentrations of polycyclic aromatic hydrocarbons in water and plankton of the Mediterranean and Black Seas. Global Biogeochem. Cycles 2011, 25, 1-14.

(57) Echeveste, P.; Dachs, J.; Berrojalbiz, N.; Agustí, S. Decrease in the abundance and viability of oceanic phytoplankton due to trace levels of complex mixtures of organic pollutants. Chemosphere 2010, 81, 161-8.

(58) Echeveste, P.; Galbán-Malagón, C.; Dachs, J.; Berrojalbiz, N.; Agustí, S. Toxicity of natural mixtures of organic pollutants in temperate and polar marine phytoplankton. Sci. Total Environ. 2016, $571,34-41$.

(59) Gasol, J. M.; Morán, X. A. G. Flow cytometric determination of microbial abundances and its use to obtain indices of community structure and relative activity, Hydrocarbon and Lipid Microbiology Protocols. Berlin, Heidelberg 2015, 159-187.

(60) Falcioni, T.; Papa, S.; Gasol, J. M. Evaluating the flowcytometric nucleic acid double-staining protocol in realistic situations of planktonic bacterial death. Appl. Environ. Microbiol. 2008, 74, 1767-1779.

(61) Sieracki, M. E.; Cucci, T. L.; Nicinski, J. Flow cytometric analysis of 5-cyano-2,3-ditolyl tetrazolium chloride activity of marine bacterioplankton in dilution cultures. Appl. Environ. Microbiol. 1999, 65, 2409-17.

(62) Kirchman, D. L.; K 'nees, E.; Hodson, R. Leucine incorporation and its potential as a measure of protein synthesis by bacteria in natural aquatic systems. Appl. Environ. Microbiol. 1985, 49, 599-607.

(63) Smith, D. C.; Azam, F. A simple, economical method for measuring bacterial protein synthesis rates in seawater using $3 \mathrm{H}$ leucine. Mar. Microb. Food Webs 1992, 6, 107-114.

(64) Hansen, H. P.; Koroleff, F. Determination of nutrients. In Methods of Seawater Analysis; Ehrhardt, M., Ed.; Weinheim, Germany, 2007, 159-228.

(65) Poretsky, R. S.; Sun, S.; Mou, X.; Moran, M. A. Transporter genes expressed by coastal bacterioplankton in response to dissolved organic carbon. Environ. Microbiol. 2010, 12, 616-627.

(66) Moran, M. A.; Satinsky, B.; Gifford, S. M.; Luo, H.; Rivers, A. R.; Chan, L.; Meng, J.; Durham, B. P.; Shen, C.; Varaljay, V. A.; Smith, C. B.; Yager, P. L.; Hopkinson, B. M. Sizing up metatranscriptomics. ISME J. 2013, 7, 237-43.

(67) Satinsky, B. M.; Gifford, S. M.; Crump, B. C.; Moran, M. A. Use of Internal Standards for Quantitative Metatranscriptome and Metagenome Analysis, 1st ed.; Elsevier Inc, 2013.

(68) del Fabbro, C.; Scalabrin, S.; Morgante, M.; Giorgi, F. M. An extensive evaluation of read trimming effects on Illumina NGS data analysis. PLoS One 2013, 8, 1-13.

(69) Zhang, J.; Kobert, K.; Flouri, T.; Stamatakis, A. PEAR: a fast and accurate Illumina Paired-End reAd mergeR. Bioinformatics 2014, 30, 614-620.

(70) Buchfink, B.; Xie, C.; Huson, D. H. Fast and sensitive protein alignment using DIAMOND. Nat. Methods 2015, 12, 59-60.

(71) Huson, D. H.; Beier, S.; Flade, I.; Górska, A.; El-Hadidi, M.; Mitra, S.; Ruscheweyh, H.-J.; Tappu, R. MEGAN community edition - Interactive exploration and analysis of large-scale microbiome sequencing data. PLoS Comput. Biol. 2016, 12, 1-12.

(72) Wickham, H.; Averick, M.; Bryan, J.; Chang, W.; McGowan, L.; François, R.; Grolemund, G.; Hayes, A.; Henry, L.; Hester, J.; Kuhn, M. Welcome to the Tidyverse. J. Open Source Soft. 2019, 4, 1686.

(73) Eddy, S. R. Accelerated profile HMM searches. PLoS Comput. Biol. 2011, 7, e1002195.

(74) Brazelton, W. J.; Baross, J. A. Abundant transposases encoded by the metagenome of a hydrothermal chimney biofilm. ISME J. 2009, $3,1420-1424$.

(75) Oksanen, J.; Blanchet, F. G.; Kindt, R.; Legendre, P.; Minchin, P. R.; O'hara, R. B. Vegan: community ecology package. $R$ Packag. Version 2. 4-6, 2018. 
(76) Dimont, E.; Shi, J.; Kirchner, R.; Hide, W. EdgeRun: An R package for sensitive, functionally relevant differential expression discovery using an unconditional exact test. Bioinformatics 2015, 31, $2589-2590$.

(77) Tolosa, I.; Bayona, J. M.; Albaigés, J. Aliphatic and polycyclic aromatic hydrocarbons and sulfur/oxygen derivatives in Northwestern Mediterranean sediments: spatial and temporal variability, fluxes, and budgets. Environ. Sci. Technol. 1996, 30, 2495-2503.

(78) Garcia-Flor, N.; Dachs, J.; Bayona, J. M.; Albaigés, J. Surface waters are a source of polychlorinated biphenyls to the coastal atmosphere of the North-Western Mediterranean Sea. Chemosphere 2009, 75, 1144-1152.

(79) Marty, J. C.; Saliot, A. Hydrocarbons (normal alkanes) in the surface microlayer of seawater. Deep-Sea Res. Oceanogr. Abstr. 1976, 23, 863-873.

(80) Guigue, C.; Tedetti, M.; Ferretto, N.; Garcia, N.; Méjanelle, L.; Goutx, M. Spatial and seasonal variabilities of dissolved hydrocarbons in surface waters from the Northwestern Mediterranean Sea: Results from one year intensive sampling. Sci. Total Environ. 2014, 466-467, $650-662$.

(81) Fourati, R.; Tedetti, M.; Guigue, C.; Goutx, M.; Garcia, N.; Zaghden, H.; Sayadi, S.; Elleuch, B. Sources and spatial distribution of dissolved aliphatic and polycyclic aromatic hydrocarbons in surface coastal waters of the Gulf of Gabès (Tunisia, Southern Mediterranean Sea). Prog. Oceanogr. 2018, 163, 232-247.

(82) Ehrhardt, M.; Petrick, G. On the composition of dissolved and particle-associated fossil fuel residues in Mediterranean surface water. Mar. Chem. 1993, 42, 57-70.

(83) Dachs, J.; Bayona, J. M.; Raoux, C.; Albaigés, J. Spatial distribution, vertical profiles and budget of polycyclic aromatic hydrocarbons in western Mediterranean. Environ. Sci. Technol. 1997, 31, 682-688.

(84) Tsapakis, M.; Apostolaki, M.; Eisenreich, S.; Stephanou, E. G. Atmospheric deposition and marine sedimentation fluxes of polycyclic aromatic hydrocarbons in the Eastern Mediterranean Basin. Environ. Sci. Technol. 2006, 40, 4922-4927.

(85) Vila-Costa, M.; Sebastián, M.; Pizarro, M.; Cerro-Gálvez, E.; Lundin, D.; Gasol, J. M.; Dachs, J. Microbial consumption of organophosphate esters in seawater under phosphorus limited conditions. Sci. Rep. 2019, 9, 233.

(86) Yooseph, S.; Nealson, K. H.; Rusch, D. B.; McCrow, J. P.; Dupont, C. L.; Kim, M.; Johnson, J.; Montgomery, R.; Ferriera, S.; Beeson, K.; Williamson, S. J.; Tovchigrechko, S.; Allen, A. E.; Zeigler, L. A.; Sutton, G.; Eisenstadt, E.; Rogers, Y. H.; Friedman, R.; Frazier, M.; Venter, J. C. Genomic and functional adaptation in surface ocean planktonic prokaryotes. Nature 2010, 468, 60-66.

(87) Guigue, C.; Tedetti, M.; Giorgi, S.; Goutx, M. Occurrence and distribution of hydrocarbons in the surface microlayer and subsurface water from the urban coastal marine area off Marseilles, Northwestern Mediterranean Sea. Mar. Pollut. Bull. 2011, 62, 2741-2752.

(88) Teira, E.; Lekunberri, I.; Gasol, J. M.; Nieto-cid, M.; Álvarezsalgado, X. A.; Figueiras, F. G. Dynamics of the hydrocarbondegrading Cycloclasticus bacteria during mesocosm-simulated oil spills. Environ. Microbiol. 2007, 9, 2551-2562.

(89) Mishamandani, S.; Gutierrez, T.; Aitken, M. D.; Redmond, M. C. DNA-based stable isotope probing coupled with cultivation methods implicates Methylophaga in hydrocarbon degradation. Front. Microbiol. 2014, 5, 1-9.

(90) Mason, O. U.; Hazen, T. C.; Borglin, S.; Chain, P. S. G.; Dubinsky, E. A.; Fortney, J. L.; Han, J.; Holman, H. Y.; Hultman, J.; Lamendella, R.; Mackelprang, R.; Malfatti, S.; Tom, L. M.; Tringe, S. G.; Woyke, T.; Zhou, J.; Rubin, E. M.; Jansson, J. K. Metagenome, metatranscriptome and single-cell sequencing reveal microbial response to Deepwater Horizon oil spill. ISME J. 2012, 6, 17151727.

(91) Joye, S. B.; Kleindienst, S.; Gilbert, J. A.; Handley, K. M.; Weisenhorn, P.; Overholt, W. A.; Kostka, J. E. Responses of microbial communities to hydrocarbon exposures. Oceanography 2016, 29, 136-149.
(92) McCarren, J.; Becker, J. W.; Repeta, D. J.; Shi, Y.; Young, C. R.; Malmstrom, R. R.; Chisholm, S. W.; DeLong, E. F. Microbial community transcriptomes reveal microbes and metabolic pathways associated with dissolved organic matter turnover in the sea. Proc. Natl. Acad. Sci. U. S. A. 2010, 107, 16420-16427.

(93) Cronin, M. T. D.; Bowers, G. S.; Sinks, G. D.; Schultz, T. W. Structure-toxicity relationships for aliphatic compounds encompassing a variety of mechanisms of toxic action to Vibrio fischeri. SAR QSAR Environ. Res. 2000, 11, 301-312.

(94) Escher, B. I.; Baumer, A.; Bittermann, K.; Henneberger, L.; König, M.; Kühnert, C.; Klüver, N. General baseline toxicity QSAR for nonpolar, polar and ionisable chemicals and their mixtures in the bioluminescence inhibition assay with Aliivibrio fischeri. Environ. Sci. Process. Impacts 2017, 19, 414-428.

(95) Rodríguez-Blanco, A.; Antoine, V.; Pelletier, E.; Delille, D.; Ghiglione, J. F. Effects of temperature and fertilization on total vs. active bacterial communities exposed to crude and diesel oil pollution in NW Mediterranean Sea. Environ. Pollut. 2010, 158, 663-673.

(96) Joye, S.; Kleindienst, S.; Peña-Montenegro, T. D. SnapShot: Microbial hydrocarbon bioremediation. Cell 2018, 172, 1336-1336.

(97) Dadon-Pilosof, A.; Conley, K. R.; Jacobi, Y.; Haber, M.; Lombard, F.; Sutherland, K. R.; Steindler, L.; Tikochinski, Y.; Richter, M.; Glöckner, F. O.; Suzuki, M. T.; West, N. J.; Genin, A.; Yahel, G. Surface properties of SAR 11 bacteria facilitate grazing avoidance. Nat. Microbiol. 2017, 2, 1608-1615.

(98) Hacker, J.; Carniel, E. Ecological fitness, genomic islands and bacterial pathogenicity. EMBO Rep. 2001, 2, 376-381.

(99) Berendonk, T. U.; Manaia, C. M.; Merlin, C.; Fatta-Kassinos, D.; Cytryn, E.; Walsh, F.; Bürgmann, H.; Sørum, H.; Norström, M.; Pons, M. N.; Kreuzinger, N.; Huovinen, P.; Stefani, S.; Schwartz, T.; Kisand, V.; Baquero, F.; Martinez, J. L. Tackling antibiotic resistance: the environmental framework. Nat. Rev. Microbiol. 2015, 13, 310317.

(100) Lauro, F. M.; Mcdougald, D.; Thomas, T.; Williams, T. J.; Egan, S.; Rice, S.; DeMaere, M. Z.; Ting, L.; Ertan, H.; Johnson, J.; Ferriera, S.; Lapidus, A.; Anderson, I.; Kyrpides, N.; Munk, A. C.; Detter, C.; Han, C. S.; Brown, M. V.; Robb, F. T.; Kjelleberg, S.; Cavicchioli, R. The genomic basis of trophic strategy in marine bacteria. Proc. Natl. Acad. Sci. U. S. A. 2009, 106, 15527-15533.

(101) Sun, S.; Badgley, B. D. Changes in microbial functional genes within the soil metagenome during forest ecosystem restoration. Soil Biol. Biochem. 2019, 135, 163-172.

(102) Dai, T.; Zhao, Y.; Ning, D.; Huang, B.; Mu, Q.; Yang, Y.; Wen, D. Dynamics of coastal bacterial community average ribosomal RNA operon copy number reflect its response and sensitivity to ammonium and phosphate. Environ. Pollut. 2020, 260, 113971. 